\title{
Discrepancies in Kappa Opioid Agonist Binding Revealed through PET Imaging
}

\author{
Michael S. Placzek, ${ }^{*}{ }^{\dagger}$ Frederick A. Schroeder, ${ }^{\dagger}$ Tao Che, ${ }^{\dagger}$ Hsiao-Ying Wey, ${ }^{\dagger}$ Ramesh Neelamegam, $^{\dagger}$ \\ Changning Wang, Bryan L. Roth, ${ }^{\dagger}, \S, \| \odot$ and Jacob M. Hooker*, ${ }^{*} \oplus$ \\ ${ }^{\dagger}$ Athinoula A. Martinos Center for Biomedical Imaging, Department of Radiology, Massachusetts General Hospital, Harvard \\ Medical School, Charlestown, Massachusetts 02129, United States \\ ${ }^{\ddagger}$ Department of Pharmacology, University of North Carolina at Chapel Hill School of Medicine, Chapel Hill, North Carolina 27516, \\ United States \\ ${ }^{\S}$ National Institute of Mental Health Psychoactive Drug Screening Program (NIMH PDSP), School of Medicine, University of \\ North Carolina at Chapel Hill School of Medicine, Chapel Hill, North Carolina 27516, United States \\ "Division of Chemical Biology and Medicinal Chemistry, Eshelman School of Pharmacy, University of North Carolina at Chapel \\ Hill, Chapel Hill, North Carolina 27516, United States
}

\begin{abstract}
Kappa opioid receptor (KOR) modulation has been pursued in many conceptual frameworks for the treatment of human pain, depression, and anxiety. As such, several imaging tools have been developed to characterize the density of KORs in the human brain and its occupancy by exogenous drug-like compounds. While exploring the pharmacology of KOR tool compounds using positron emission tomography (PET), we observed discrepancies in the apparent competition binding as measured by changes in binding potential $\left(\mathrm{BP}_{\mathrm{ND}}\right.$, binding potential with respect to non-displaceable uptake). This prompted us to systematically look at the relationships between

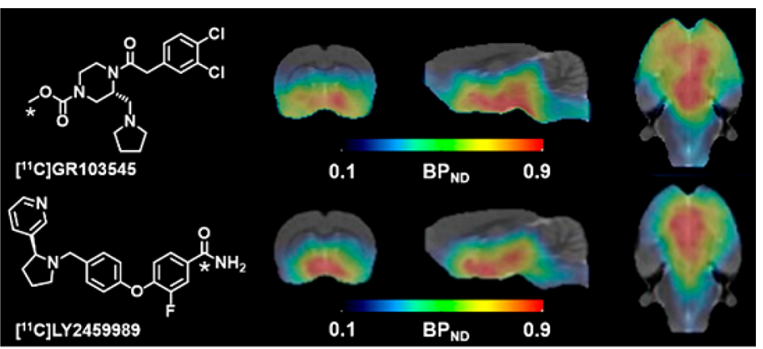
baseline $\mathrm{BP}_{\mathrm{ND}}$ maps for three common KOR PET radioligands, the antagonists $\left[{ }^{11} \mathrm{C}\right] \mathrm{LY} 2795050$ and $\left[{ }^{11} \mathrm{C}\right] \mathrm{LY} 2459989$, and the agonist $\left[{ }^{11} \mathrm{C}\right] \mathrm{GR} 103545$. We then measured changes in $\mathrm{BP}_{\mathrm{ND}}$ using kappa antagonists (naloxone, naltrexone, LY2795050, JDTic, nor-BNI), and found $\mathrm{BP}_{\mathrm{ND}}$ was affected similarly between $\left[{ }^{11} \mathrm{C}\right] \mathrm{GR} 103545$ and $\left[{ }^{11} \mathrm{C}\right] \mathrm{LY} 2459989$. Longitudinal PET studies with nor-BNI and JDTic were also examined, and we observed a persistent decrease in $\left[{ }^{11} \mathrm{C}\right] \mathrm{GR} 103545 \mathrm{BP}_{\mathrm{ND}}$ up to 25 days after drug administration for both nor-BNI and JDTic. Kappa agonists were also administered, and butorphan and GR89696 (racemic GR103545) impacted binding to comparable levels between the two radiotracers. Of greatest significance, kappa agonists salvinorin A and U-50488 caused dramatic reductions in $\left[{ }^{11} \mathrm{C}\right] \mathrm{GR} 103545 \mathrm{BP}_{\mathrm{ND}}$ but did not change $\left[{ }^{11} \mathrm{C}\right] \mathrm{LY} 2459989$ binding. This discrepancy was further examined in dose-response studies with each radiotracer as well as in vitro binding experiments.
\end{abstract}

KEYWORDS: $\left[{ }^{11} \mathrm{C}\right] \mathrm{GR} 103545,\left[{ }^{11} \mathrm{C}\right]$ LY2459989, kappa opioid receptor, PET, kappa agonist, kappa antagonist

\section{INTRODUCTION}

The opioid receptors (ORs) belong to the superfamily of G-protein-coupled receptors (GPCRs) and consist of three major subtypes: mu, kappa, and delta. ${ }^{1-4}$ While mu has been the primary target of opioid analgesics, kappa opioid receptors (KORs) are the most abundant ORs in the human brain and a key regulator in a number of physiological systems, such as pain regulation, motor function, stress response, and mood control., ${ }^{5,6}$ As a result, extensive efforts have been made to understand KOR signaling, ${ }^{7-9}$ endogenous dynorphin-mediated receptor activation, ${ }^{10,11}$ and discovery and pharmacology of exogenous ligands that bind to KORs. Early KOR drug discovery focused on development of agonists that produced analgesic effects without the liabilities associated with mu opioids, such as respiratory depression and addiction. ${ }^{12}$ Unfortunately, it was discovered that kappa agonists are aversive in humans, causing dysphoric, depressive mood states and hallucinations. ${ }^{13,14}$ Recently, an exciting new class of kappa agonists, termed G-protein-biased agonists, have been developed. ${ }^{15-18}$ These drugs have demonstrated analgesic efficacy in vitro and in vivo in animal pain models, while largely avoiding dysphoric and other aversive effects. ${ }^{19-21}$ Conversely, kappa antagonists have been developed to treat negative mood states, and have progressed into phase I clinical trials to potentially treat addiction, depression, and anxiety. $^{22-24}$ Together, kappa agonist and antagonist drug discovery has been heavily pursued for a wide range of health disorders from pain to neuropsychiatric illnesses. To support this research, continued development and validation of tools to study KOR pharmacology in vivo such as positron emission tomography (PET) is essential.

Received: June 15, 2018

Accepted: September 13, 2018

Published: September 13, 2018 


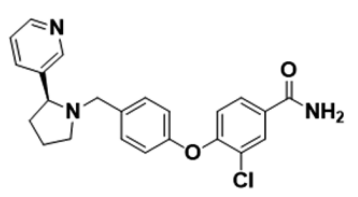

LY2795050, $\left[{ }^{11} \mathrm{C}\right] L Y 2795050$

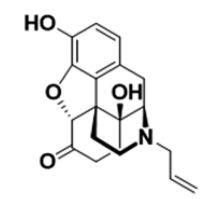

naloxone

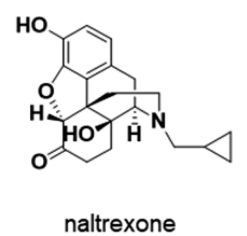

naltrexone

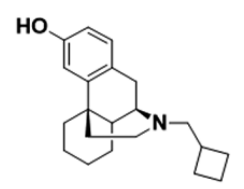

butorphan (MCL-101)

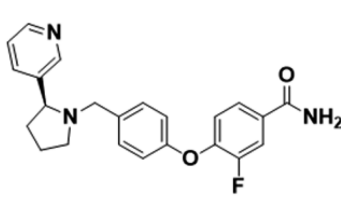

LY2459989, [ [11 C]LY2459989

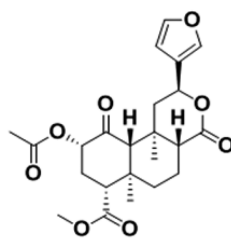

salvinorin $A$

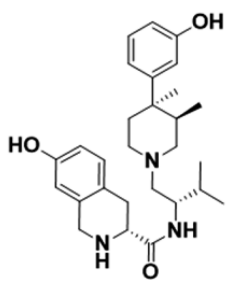

JDTic

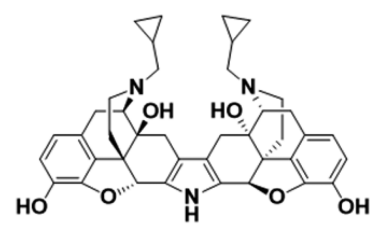

nor-binaltorphimine (nor-BNI)

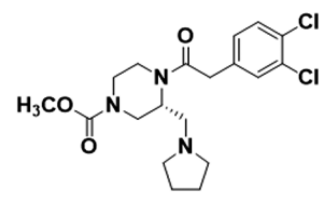

GR103545, [11 C]GR103545
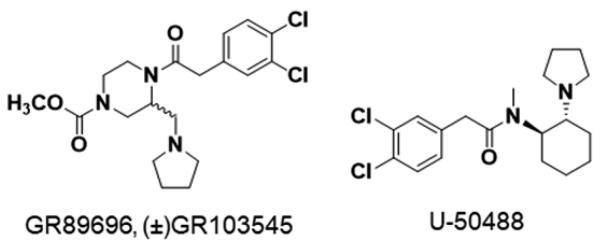

U-50488

Figure 1. Kappa opioid receptor ligands and PET radiotracers used in this work.

Several KOR agonist and antagonist pharmacophores have been developed and investigated (Figure 1). The KOR antagonists can be further divided into short- and long-acting based on their effective duration of action. Naloxone and naltrexone are short-acting KOR antagonists, but also have affinity for mu and delta ORs. The aminobenzyloxyarylamides are selective KOR antagonists originally reported by Lilly, later entering clinical trials for major depressive disorder and substance abuse disorder (LY2456302, CERC-501). ${ }^{25,26}$ These compounds were the first KOR-selective short-acting antagonists. Since this discovery, two compounds from the aminobenzyloxyarylamide class have been radiolabeled with $\mathrm{C}-11$ and F-18, and are now clinically validated KOR PET radiotracers. ${ }^{27-29}$ JDTic and nor-BNI are long-acting KOR antagonists that, while structurally unique to one another, both have a delayed onset and long duration of action on KORmediated effects. ${ }^{30,31}$ Nor-BNI was the first selective KOR antagonist and has been used as a pharmacological tool in KOR research, particularly in animal behavior studies to blunt KORmediated effects. ${ }^{32-34}$ JDTic was evaluated in phase I clinical trials as potential treatment for cocaine abuse, but the study was terminated due to adverse events. ${ }^{22}$ One of the earliest KORselective agonists was U-50488. This phenylacetamide is a potent and selective KOR agonist with analgesic activity in vivo. ${ }^{35} \mathrm{U}-50488$, and structural analog U-69593, have been routinely used to interrogate KOR activation in both neurobiological and behavioral research. ${ }^{36-38}$ Derivation of this class led to $( \pm)$ GR89696 and GR103545 (active enantiomer, $(-)$, of GR89696), ${ }^{39}$ an ultra-potent kappa agonist that was later radiolabeled with carbon-11 and studied with PET. ${ }^{40,41}$ Salvinorin A is a natural product that belongs to the neoclerodane diterpene chemical class. Its chemical scaffold is unique compared to most KOR agonists (salvinorin A and collybolide analogs are the only non-nitrogenous KOR agonists), but exhibits potent affinity and extreme selectivity for KORs. ${ }^{42,43}$ Since its discovery, several potent salvinorin derivatives have been discovered with unique biochemical and pharmacological properties. ${ }^{16,19,44}$
Over the past 15 years, two classes of radiotracers for in vivo imaging of KORs with PET have been developed, and both are currently validated for human imaging. The KOR agonist $\left[{ }^{11} \mathrm{C}\right]$ GR103545, was the first KOR PET radiotracer evaluated clinically (Figure 1). ${ }^{45}$ Unfortunately, slow binding kinetics and ultra-potency (requiring high specific activity to maintain microdose levels) excluded this radiotracer from continued use in humans, although preclinical studies have successfully utilized this radiotracer. ${ }^{46}$ To circumvent this problem, a series of KOR antagonist PET radiotracers were discovered and evaluated in non-human primates and humans. ${ }^{27-29,47,48}$ Thus, $\left[{ }^{11} \mathrm{C}\right] \mathrm{LY} 2795050$ was the first clinically validated KOR antagonist radiotracer, although its moderate KOR selectivity and low specific binding led to the development of $\left[{ }^{11} \mathrm{C}\right] \mathrm{LY} 2459989$ and $\left[{ }^{18} \mathrm{~F}\right]$ LY2459989 (Figure 1). ${ }^{28,29}$ Previous PET studies on KORs have focused on clinical validation of the aforementioned radiotracers and in vivo drug-occupancy measurements of KOR antagonists (e.g., PF-04455242, LY2456302). ${ }^{45,49}$ In either clinical or preclinical PET studies, reports of drug occupancy measurements with KOR agonists are lacking. As KOR agonist medicinal chemistry continues to develop (largely around G-protein-biased agonists), ${ }^{19,50,51}$ it will be important to have PET radiotracers capable of measuring in vivo occupancy for both KOR agonists and antagonists. Pharmacological PET experiments with agonist drug challenge can prove difficult, especially when studying dynamic protein targets such as GPCRs. ${ }^{52,53}$ In addition, a thorough evaluation and comparison of the two classes of KOR radiotracers in rodents has not been reported. Given the broad therapeutic application of KOR targeting drugs and genetic and behavior rodent models used to study KORs, it is important to understand which KOR radiotracers are best suited for measuring drug occupancy of KOR ligands.

In this study, KOR PET studies in Sprague-Dawley rats were conducted to determine differences, if any, of radioligand sensitivity toward drug challenge with an array of KOR-specific ligands (agonists and antagonists). This work was conducted to compare three common KOR PET radioligands: the antagonists $\left[{ }^{11} \mathrm{C}\right]$ LY2795050 and $\left[{ }^{11} \mathrm{C}\right] \mathrm{LY} 2459989$, and the agonist 

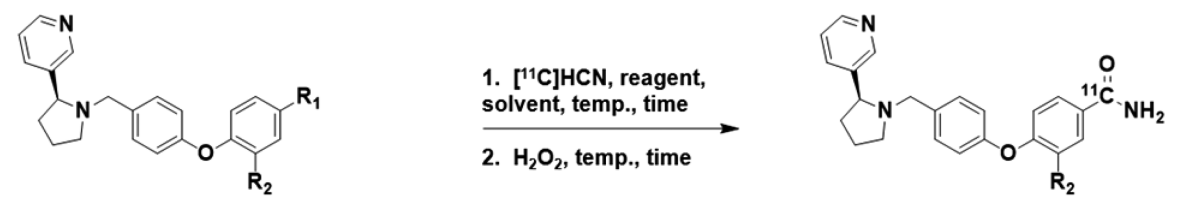

\begin{tabular}{|c|c|c|c|c|c|c|c|c|}
\hline $\mathrm{R}_{1}$ & $\mathrm{R}_{2}$ & Reagents & Solvent & $\begin{array}{l}\text { 1. Cyanation } \\
\text { (temp, time) }\end{array}$ & $\begin{array}{l}\text { 2. Hydrolysis } \\
\text { (temp, time) }\end{array}$ & $\begin{array}{l}\text { Radiochemical } \\
\text { Yield (\%) }\end{array}$ & $\begin{array}{l}\text { Synthesis Time } \\
\text { (min) }\end{array}$ & $\begin{array}{l}\text { Specific Activity } \\
(\mathrm{mCi} / \mathrm{nmol})\end{array}$ \\
\hline 1 & $\mathrm{Cl}$ & $\begin{array}{c}\mathrm{Pd}_{2} \mathrm{dba}_{3}, \mathrm{dppf}, \\
\mathrm{K}_{2} \mathrm{CO}_{3}\end{array}$ & DMF & $80^{\circ} \mathrm{C}, 5 \mathrm{~min}$ & $80^{\circ} \mathrm{C}, 5 \mathrm{~min}$ & 12 & 45 & 0.64 \\
\hline $\mathrm{Br}$ & $\mathrm{Cl}$ & $\begin{array}{c}\mathrm{Pd}_{2} \mathrm{dba}_{3}, \mathrm{dppf}, \\
\mathrm{K}_{2} \mathrm{CO}_{3}\end{array}$ & DMF & $80^{\circ} \mathrm{C}, 5 \mathrm{~min}$ & $80^{\circ} \mathrm{C}, 5 \mathrm{~min}$ & 10 & 38 & 1.1 \\
\hline $\mathrm{Br}$ & $\mathrm{Cl}$ & $\begin{array}{c}\mathrm{Pd}\left(\mathrm{PPh}_{3}\right)_{4}, \\
\mathrm{~K}_{2} \mathrm{CO}_{3}\end{array}$ & DMSO & $110^{\circ} \mathrm{C}, 5 \mathrm{~min}$ & $23^{\circ} \mathrm{C}, 2 \mathrm{~min}$ & 20 & 35 & 1.3 \\
\hline $\mathrm{Br}$ & $\mathrm{Cl}$ & $\begin{array}{c}\mathrm{Pd}\left(\mathrm{PPh}_{3}\right)_{4}, \\
\mathrm{~K}_{2} \mathrm{CO}_{3}\end{array}$ & DMSO & $\mu$ wave $80 \mathrm{w}, 20 \mathrm{~s}$ & $23^{\circ} \mathrm{C}, 2 \mathrm{~min}$ & 21 & 30 & 2.5 \\
\hline $\mathrm{Br}$ & $\mathrm{F}$ & $\begin{array}{c}\mathrm{Pd}\left(\mathrm{PPh}_{3}\right)_{4}, \\
\mathrm{~K}_{2} \mathrm{CO}_{3}\end{array}$ & DMSO & $\mu$ wave $80 \mathrm{w}, 20 \mathrm{~s}$ & $23^{\circ} \mathrm{C}, 2 \mathrm{~min}$ & 29 & 30 & 2.7 \\
\hline
\end{tabular}

Figure 2. Improved synthesis of $\left[{ }^{11} \mathrm{C}\right] \mathrm{LY} 2795050$ and $\left[{ }^{11} \mathrm{C}\right] \mathrm{LY} 2459989$. Microwave heating resulted in high radiochemical yield, shorter total synthesis time, and improved specific activity compared to conventional conditions.

$\left[{ }^{11} \mathrm{C}\right] \mathrm{GR} 103545$ (Figure 1). Baseline PET scans with the agonist radiotracer $\left[{ }^{11} \mathrm{C}\right] \mathrm{GR} 103545$ were compared to the antagonist radiotracer $\left[{ }^{11} \mathrm{C}\right] \mathrm{LY} 2459989$ to assess any regional specific binding differences. Binding potential with respect to non-displaceable binding $\left(\mathrm{BP}_{\mathrm{ND}}\right)$ was calculated with PMOD using Logan Reference analysis. Blocking experiments with KOR antagonist drugs (naltrexone, naloxone, LY2795050, JDTic, nor-BNI) were conducted with PET to measure competitive binding dynamics for each radiotracer. Lastly, several KOR agonists (butorphan, U-50488, GR89696, and salvinorin A) were administered in blocking experiments to measure each radioligand's displacement by agonist drug challenge. Lastly, GR103545 and LY2459989 in vitro binding was evaluated in wild-type and mutated KORs (D138N).

\section{RESULTS AND DISCUSSION}

Radiochemistry. Previous synthesis of $\left[{ }^{11} \mathrm{C}\right] \mathrm{LY} 2795050$ and $\left[{ }^{11} \mathrm{C}\right]$ LY2459989 was accomplished by heating the aryl iodide precursor and $\mathrm{Pd}_{2}(\mathrm{dba})_{3} / \mathrm{dppf}$, with ${ }^{11} \mathrm{C}-\mathrm{HCN}$ for $5 \mathrm{~min}$ followed by thermal hydrolysis ( $5 \mathrm{~min}$ with $\mathrm{H}_{2} \mathrm{O}_{2}$ ) using conventional heating at $80{ }^{\circ} \mathrm{C} .{ }^{28}$ In an effort to expedite this process and improve specific activity, the aryl bromide precursor was subjected to rapid microwave heating followed by hydrolysis at ambient temperature. We observed rapid conversion of aryl bromide to ${ }^{11} \mathrm{C}$-aryl-CN, and highest radiochemical yields were obtained using $80 \mathrm{~W}$ of power for $20 \mathrm{~s}$. At this power and time, we observed nearly complete consumption of ${ }^{11} \mathrm{C}-\mathrm{HCN}$ to ${ }^{11} \mathrm{C}$ aryl-CN. Immediately following microwave heating, $\mathrm{H}_{2} \mathrm{O}_{2}$ was added and the reaction stirred for $2 \mathrm{~min}$ at ambient temperature. With this process, we reduced the reaction time from 10 to 2.33 min while improving radiochemical yield (from 12 to $21 \%$ ) and improved specific activity (from 0.64 to $2.2-3.0 \mathrm{mCi} / \mathrm{nmol}$ at EOS). Using this method, similar radiochemical yields were obtained for both $\left[{ }^{11} \mathrm{C}\right] \mathrm{LY} 2795050$ and $\left[{ }^{11} \mathrm{C}\right] \mathrm{LY} 2459989$ (Figure 2). $\left[{ }^{11} \mathrm{C}\right] \mathrm{GR} 103545$ was synthesized from the normethylcarbamoyl precursor according to methods identical to those previously reported. ${ }^{46}$

PET Imaging Comparison of $\left[{ }^{11} \mathrm{C}\right] \mathrm{GR} 103545$ and $\left[{ }^{11}\right.$ C]LY2459989 in Rats. Initial studies measuring rat KOR binding with PET were performed with a first generation KOR antagonist radiotracer, $\left[{ }^{11} \mathrm{C}\right] \mathrm{LY} 2795050$. In rat brain, we observed low specific binding and poor dynamic range in regions known to have high KOR expression: nucleus accumbens (NACC), amygdala (AG), caudate putamen (CPU), hypothalamus (HTH), olfactory (OLF), midbrain (MB), thalamus (THA), and periaqueductal gray (PAG). ${ }^{54-56}$ Given the relatively low abundance of KOR density in the rat brain compared to both human and non-human primates, ${ }^{55}$ we averaged several regions of interest (ROIs), selected based on highest specific binding, and designated as "high binding" (nucleus accumbens, amygdala, caudate putamen, hypothalamus, midbrain, olfactory, thalamus, periaqueductal gray, ventral tegmental area). This averaged ROI has been used to examine $\left[{ }^{11} \mathrm{C}\right] \mathrm{LY} 2795050$ (high binding $\mathrm{BP}_{\mathrm{ND}}=$ $0.351 \pm 0.047, n=3)^{56,57}$ and all other KOR radiotracers examined in this work. Fortunately, during our studies a second generation KOR antagonist PET radiotracer was reported, ${ }^{11}$ C $]$ LY2459989. ${ }^{28}$ Since no prior rodent PET studies were reported with $\left[{ }^{11} \mathrm{C}\right] \mathrm{LY} 2459989$, we measured regional-specific binding and compared to $\left[{ }^{11} \mathrm{C}\right] \mathrm{LY} 2795050 .\left[{ }^{11} \mathrm{C}\right] \mathrm{LY} 2459989$ demonstrated higher specific binding in rat brain regions known to have high KOR expression (high binding $\mathrm{BP}_{\mathrm{ND}} 0.560 \pm 0.046$, $n=5)$. In addition, $\left[{ }^{11} \mathrm{C}\right] \mathrm{LY} 2459989$ was compared to KOR agonist PET radiotracer $\left[{ }^{11} \mathrm{C}\right] \mathrm{GR} 103545$ to determine differences, if any, of regional specific binding patterns in rats (Figure 3 ). Both radiotracers exhibited highest specific binding $\left(\mathrm{BP}_{\mathrm{ND}}\right)$ in the hypothalamus followed by moderate uptake in the ventral tegmental area, periaqueductal gray, nucleus accumbens, midbrain, and amygdala. Lowest uptake was observed in the cerebellum, and was used as a reference region to calculate $\mathrm{BP}_{\mathrm{ND}}$ (Logan Reference analysis). Our data indicate a strong correlation of regional specific binding patterns between the antagonist $\left[{ }^{11} \mathrm{C}\right]$ LY2459989 and the agonist $\left[{ }^{11} \mathrm{C}\right] \mathrm{GR} 103545$ (Figure 3). We also compared regional brain time-activity curves for each radioligand at baseline and following naloxone pretreatment. These data indicate favorable kinetics for all three ligands in rats, despite the slow washout in humans previously reported for $\left[{ }^{11} \mathrm{C}\right] \mathrm{GR} 103545$ (see Supporting Information (SI) for timeactivity curves).

Blocking Studies with KOR Antagonists. We previously reported in vivo KOR occupancy of salvinorin A and agonistinduced receptor binding dynamics using $\left[{ }^{11} \mathrm{C}\right] \mathrm{GR} 103545$ PET. ${ }^{46}$ This work was originally investigated with $\left[{ }^{11} \mathrm{C}\right] \mathrm{LY} 2795950$, and 

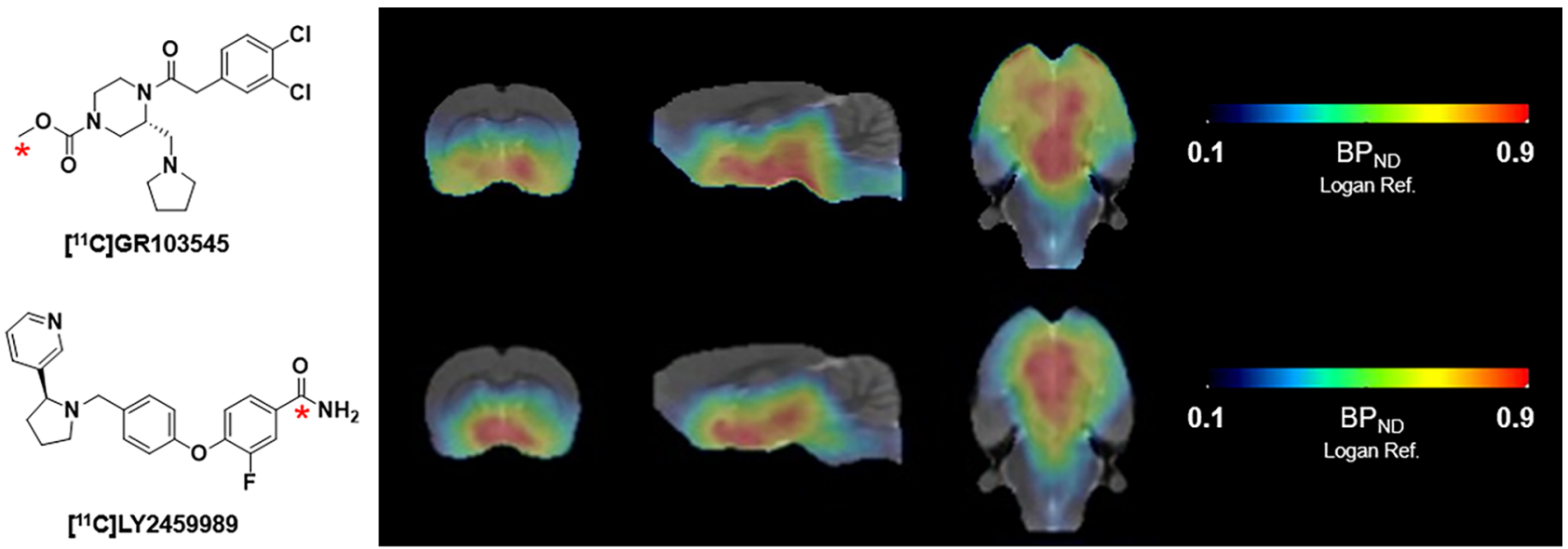

[11C]LY2459989

\begin{tabular}{|c|c|c|c|c|c|c|c|c|c|c|c|c|c|c|c|c|c|}
\hline & & HTH & VTA & PAG & NACC & MB & AG & OLF & INS & THA & CPU & HC & CIN & FRT & MTR & CBL & $\begin{array}{c}\text { High } \\
\text { Binding } \\
\text { Ave } \\
\end{array}$ \\
\hline $\begin{array}{c}\left.{ }^{11} \mathrm{C}\right] \mathrm{GR} 103545 \\
\text { baseline } \\
n=11\end{array}$ & $\begin{array}{c}\text { BP }_{\mathrm{ND}} \\
\text { Logan Ref. }\end{array}$ & $\begin{array}{c}0.868 \\
\pm \\
0.176 \\
\end{array}$ & $\begin{array}{c}0.691 \\
\pm \\
0.170 \\
\end{array}$ & $\begin{array}{c}0.626 \\
\pm \\
0.187\end{array}$ & $\begin{array}{c}0.637 \\
\pm \\
0.150 \\
\end{array}$ & $\begin{array}{c}0.551 \\
\pm \\
0.160\end{array}$ & $\begin{array}{c}0.504 \\
\pm \\
0.156\end{array}$ & $\begin{array}{c}0.593 \\
\pm \\
0.145 \\
\end{array}$ & $\begin{array}{c}0.527 \\
\pm \\
0.166 \\
\end{array}$ & $\begin{array}{c}0.440 \\
\pm \\
0.149 \\
\end{array}$ & $\begin{array}{c}0.474 \\
\pm \\
0.147\end{array}$ & $\begin{array}{c}0.271 \\
\pm \\
0.111\end{array}$ & $\begin{array}{c}0.068 \\
\pm \\
0.121 \\
\end{array}$ & $\begin{array}{c}0.072 \\
\pm \\
0.152 \\
\end{array}$ & $\begin{array}{c}0.047 \\
\pm \\
0.097\end{array}$ & - & $\begin{array}{c}0.598 \\
\pm \\
0.130\end{array}$ \\
\hline $\begin{array}{c}{\left[{ }^{11} \mathrm{C}\right] \mathrm{LY} \mathbf{2 4 5 9 9 8 9}} \\
\text { baseline } \\
n=5\end{array}$ & $\begin{array}{c}\text { BP }_{\mathrm{ND}} \\
\text { Logan Ref. }\end{array}$ & $\begin{array}{c}0.884 \\
\pm \\
0.146\end{array}$ & $\begin{array}{c}0.645 \\
\pm \\
0.040\end{array}$ & $\begin{array}{c}0.622 \\
\pm \\
0.105\end{array}$ & $\begin{array}{c}0.586 \\
\pm \\
0.046\end{array}$ & $\begin{array}{c}0.609 \\
\pm \\
0.055\end{array}$ & $\begin{array}{c}0.447 \\
\pm \\
0.053\end{array}$ & $\begin{array}{c}0.436 \\
\pm \\
0.097\end{array}$ & $\begin{array}{c}0.240 \\
\pm \\
0.097\end{array}$ & $\begin{array}{c}0.460 \\
\pm \\
0.056\end{array}$ & $\begin{array}{c}0.354 \\
\pm \\
0.055\end{array}$ & $\begin{array}{c}0.297 \\
\pm \\
0.038\end{array}$ & $\begin{array}{c}-0.021 \\
\pm \\
0.046\end{array}$ & $\begin{array}{c}-0.145 \\
\pm \\
0.089\end{array}$ & $\begin{array}{c}-0.127 \\
\pm \\
0.059\end{array}$ & - & $\begin{array}{c}0.560 \\
\pm \\
0.046\end{array}$ \\
\hline
\end{tabular}

High Binding Average Regions = HTH, VTA, PAG, NACC, MB, AG, OLF, THA, CPU

Figure 3. Baseline specific binding comparison of $\left[{ }^{11} \mathrm{C}\right] \mathrm{GR} 103545$ and $\left[{ }^{11} \mathrm{C}\right]-\mathrm{LY} 2459989$ in Sprague-Dawley rats. Regional specific binding $\left(\mathrm{BP}_{\mathrm{ND}}\right)$ was calculated using Logan Reference analysis using cerebellum as reference region. PET images represent average $\mathrm{BP}_{\mathrm{ND}}$ at baseline and were fused onto Rat-T2-MRI template. $\mathrm{BP}_{\mathrm{ND}}=$ mean \pm standard deviation. Red asterisk on structures indicates radiolabel position. Brain region abbreviations, $\mathrm{HTH}=$ hypothalamus, $\mathrm{VTA}=$ ventral tegmental area, $\mathrm{PAG}=$ periaqueductal gray, $\mathrm{NACC}=$ nucleus accumbens, $\mathrm{MB}=$ midbrain, $\mathrm{AG}=$ amygdala, $\mathrm{OLF}=$ olfactory tubercle, $\mathrm{INS}=$ insular cortex, $\mathrm{THA}=$ thalamus, $\mathrm{CPU}=$ caudate putamen, $\mathrm{HC}=$ hippocampus, $\mathrm{CIN}=$ cingulate cortex, $\mathrm{FRT}=$ frontal cortex, $\mathrm{MTR}=$ motor cortex, $\mathrm{CBL}=$ cerebellum. High Binding = average of HTH, VTA, PAG, NACC, MB, AG, OLF, THA, and CPU.

again with $\left[{ }^{11} \mathrm{C}\right] \mathrm{LY} 2459989$, but both ligands failed to demonstrate a dose-occupancy relationship with salvinorin A. These results prompted a thorough examination of the sensitivity of KOR radiotracers toward pharmacological challenge with KOR targeting ligands. Table 1 is a summary of all blocking studies conducted with each radiotracer. Comparison of $\left[{ }^{11} \mathrm{C}\right]$ GR103545 and $\left[{ }^{11} \mathrm{C}\right]$ LY2459989 was first conducted by pretreating animals with short-acting nonspecific and specific KOR antagonists (naltrexone, naloxone, LY2795050) to measure changes in $\left[{ }^{11} \mathrm{C}\right] \mathrm{LY} 2459989$ or $\left[{ }^{11} \mathrm{C}\right] \mathrm{GR} 013545 \mathrm{BP}{ }_{\mathrm{ND}}$. Pretreatment with naltrexone $(2 \mathrm{mg} / \mathrm{kg}$, i.v., $5 \mathrm{~min}$ pretreatment $)$ followed by $\mathrm{KOR}$ radiotracer bolus (i.v., $\sim 1 \mathrm{mCi}$ ), significantly reduced high binding $\mathrm{BP}_{\mathrm{ND}}$ of both $\left[{ }^{11} \mathrm{C}\right] \mathrm{GR} 103545\left(\mathrm{BP}_{\mathrm{ND}}<1 \%\right.$ of baseline) and $\left[{ }^{11} \mathrm{C}\right] \mathrm{LY} 2459989\left(\mathrm{BP}_{\mathrm{ND}}<1 \%\right.$ of baseline $)$. Pretreatment with naloxone $(2 \mathrm{mg} / \mathrm{kg}$, i.v., 5 min pretreatment) resulted in a similar marked decrease in specific binding for $\left[{ }^{11} \mathrm{C}\right] \mathrm{GR} 103545\left(\mathrm{BP}_{\mathrm{ND}}=20 \%\right.$ of baseline $)$ and $\left[{ }^{11} \mathrm{C}\right] \mathrm{LY} 2459989$ $\left(\mathrm{BP}_{\mathrm{ND}}=16 \%\right.$ of baseline $)$. In addition to naltrexone and naloxone, which have affinity for all OR subtypes, we attempted blocking experiments with the KOR-specific antagonist LY2795050. LY2795050 (i.v., 5 min pretreatment) dose-dependently blocks $\left[{ }^{11} \mathrm{C}\right]$ GR103545-specific binding at $0.032 \mathrm{mg} / \mathrm{kg}\left(\mathrm{BP}_{\mathrm{ND}}=66 \%\right.$ of baseline $)$ and $0.32 \mathrm{mg} / \mathrm{kg}\left(\mathrm{BP}_{\mathrm{ND}}=17 \%\right.$ of baseline $)$. Specific binding of $\left[{ }^{11} \mathrm{C}\right] \mathrm{LY} 2459989$ is also significantly reduced when animals are pretreated with $0.32 \mathrm{mg} / \mathrm{kg}$ of LY2795050 $\left(\mathrm{BP}_{\mathrm{ND}}=\right.$ $19 \%$ of baseline).

To further examine any possible discrepancies in KOR occupancy measurements, we administered KOR-specific antagonists nor-BNI and JDTic to rats prior to radiotracer bolus (Table 1). Nor-BNI and JDTic are unique KOR antagonists that produce sustained antagonistic effects on KOR-mediated behavior ${ }^{58}$ and signaling $^{59}$ (e.g., behavioral effects by nor-BNI have been reported to persist up to 86 days in rodents). ${ }^{60}$ Nor-BNI is a bivalent ligand derived from naltrexone. JDTic is a 4-phenylpiperidine derivative that also displays high affinity and selectivity for KORs. A pharmacokinetic (PK) study was previously reported describing the long duration of action for both nor-BNI and JDTic. ${ }^{61}$ Contrary to behavior and signaling data, both drugs are rapidly absorbed and eliminated from plasma and exhibit low brain uptake after i.p. administration (nor-BNI $t_{\max }=30 \mathrm{~min}, C_{\max , \text { brain }}=443 \mathrm{ng} \mathrm{mL}^{-1}$; JDTic $t_{\max }=$ $\left.30 \mathrm{~min}, C_{\text {max,brain }}=71 \mathrm{ng} \mathrm{mL}^{-1}\right){ }^{61}$ To compare with these PK experiments, we administered drugs at $10 \mathrm{mg} / \mathrm{kg}$ (i.p.), and allowed a $30 \mathrm{~min}$ uptake period prior to radiotracer bolus. NorBNI reduced $\left[{ }^{11} \mathrm{C}\right] \mathrm{GR} 013545$ specific binding (high binding $\mathrm{BP}_{\mathrm{ND}}=47 \pm 15 \%$ of baseline; $n=2$ ), and to a lesser extent, $\left[{ }^{11} \mathrm{C}\right] \mathrm{LY} 2459989$ specific binding (high binding $\mathrm{BP}_{\mathrm{ND}}=62 \%$ of baseline). JDTic reduced $\left[{ }^{11} \mathrm{C}\right] \mathrm{GR} 103545$ specific binding (high binding $\mathrm{BP}_{\mathrm{ND}}=46 \pm 1 \%$ of baseline; $n=2$ ) but only slightly reduced $\left[{ }^{11} \mathrm{C}\right]$ LY2459989 specific binding (high binding $\mathrm{BP}_{\mathrm{ND}}=84 \%$ of baseline). It has been estimated from PK studies that peak unbound brain levels at $30 \mathrm{~min}$ for JDTic and nor-BNI are $4 \mathrm{nM}$ and $26 \mathrm{nM}$. As mentioned in that study, those unbound brain concentrations are likely inaccurate, because both JDTic and nor-BNI would produce maximal occupancy at that dose $(10 \mathrm{mg} / \mathrm{kg})$ given their sub-nanomolar affinity for $\mathrm{KOR}^{8}$ Consistent with their speculation, our data indicates considerable occupancy for both nor-BNI and JDTic when measured with $\left[{ }^{11} \mathrm{C}\right] \mathrm{GR} 103545$, but we observed lower occupancy when measured with $\left[{ }^{11} \mathrm{C}\right]$ LY2795050 (Table 1).

To gain a better understanding of the long duration of action for both nor-BNI and JDTic in vivo, we measured longitudinal effects of nor-BNI and JDTic on $\left[{ }^{11} \mathrm{C}\right]$ GR103545 binding in vivo with PET. Following our initial PET studies with nor-BNI and 
Table 1. Pharmacological PET Experiments Conducted with KOR Radiotracer in Rats ${ }^{a}$

\begin{tabular}{|c|c|c|c|c|c|c|c|c|}
\hline & \multirow[b]{2}{*}{ drug } & \multirow[b]{2}{*}{ dose $(\mathrm{mg} / \mathrm{kg})$} & \multicolumn{2}{|c|}{ [11 C]GR103545 } & \multicolumn{2}{|c|}{$\left[{ }^{11}\right.$ C]LY2459989 } & \multicolumn{2}{|c|}{$\left[{ }^{11}\right.$ C]LY2795050 } \\
\hline & & & $\mathbf{B P}_{\mathrm{ND}}$ & $\%$ of baseline & $\mathbf{B P}_{\mathrm{ND}}$ & $\%$ of baseline & $\mathbf{B P}_{\mathrm{ND}}$ & $\%$ of baseline \\
\hline & Baseline & - & $\begin{array}{c}0.598 \pm 0.130 \\
n=11\end{array}$ & 100 & $\begin{aligned} 0.560 & \pm 0.046 \\
n & =5\end{aligned}$ & 100 & $\begin{aligned} 0.351 & \pm 0.047 \\
n & =3\end{aligned}$ & 100 \\
\hline \multirow{10}{*}{ 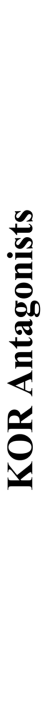 } & naltrexone & 2 & $\begin{array}{c}-0.009 \pm 0.080 \\
n=3\end{array}$ & $<1$ & $\begin{array}{c}-0.004 \pm 0.090 \\
n=3\end{array}$ & $<1$ & - & - \\
\hline & naloxone & 2 & 0.119 & 20 & 0.092 & 16 & $\begin{array}{c}0.078 \pm 0.019 \\
n=2\end{array}$ & $22 \pm 5$ \\
\hline & LY2795050 & 0.032 & 0.394 & 66 & - & - & - & - \\
\hline & & 0.32 & 0.099 & 17 & 0.106 & 19 & 0.081 & 23 \\
\hline & JDTic $30 \mathrm{~min}$ & 10 & $\begin{array}{c}0.276 \pm 0.006 \\
n=2\end{array}$ & $46 \pm 1$ & 0.471 & 84 & - & - \\
\hline & JDTIC $3 \mathrm{~h}$ & 10 & 0.248 & 41 & - & - & - & - \\
\hline & JDTIC 25 day & 10 & $\begin{array}{c}0.093 \pm 0.106 \\
n=2\end{array}$ & 16 & - & - & - & - \\
\hline & nor-BNI $30 \mathrm{~min}$ & 10 & $\begin{array}{c}0.279 \pm 0.187 \\
n=2\end{array}$ & $47 \pm 15$ & 0.347 & 62 & - & - \\
\hline & nor-BNI $3 \mathrm{~h}$ & 10 & 0.291 & 49 & - & - & - & - \\
\hline & nor-BNI 25 day & 10 & 0.226 & 38 & - & - & - & - \\
\hline \multirow{6}{*}{ 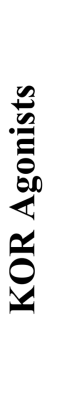 } & butorphan (MCL-101) & 0.1 & - & - & 0.472 & 84 & - & - \\
\hline & & 1 & 0.205 & 34 & 0.163 & 29 & - & - \\
\hline & GR89696 ( \pm GR103545 & 0.2 & 0.009 & 2 & $\begin{array}{c}0.120 \pm 0.020 \\
n=3\end{array}$ & $21 \pm 4$ & - & - \\
\hline & $( \pm) \mathrm{U}-50488$ & 1 & 0.113 & 19 & $\begin{array}{c}0.533 \pm 0.098 \\
n=2\end{array}$ & $95 \pm 17$ & - & - \\
\hline & salvinorin $\mathrm{A}$ & 0.6 & 0.374 & 63 & 0.502 & $\begin{array}{l}90 \pm 26 \\
n=2\end{array}$ & 0.326 & 93 \\
\hline & & 1.8 & 0.156 & 26 & 0.419 & 75 & - & - \\
\hline
\end{tabular}

${ }^{a} \mathrm{BP}_{\mathrm{ND}}$ 's represent data from high binding ROIs. Further studies with $\left[{ }^{11} \mathrm{C}\right] \mathrm{LY} 2795050$ were replaced by the improved KOR antagonist radiotracer $\left[{ }^{11} \mathrm{C}\right]$ LY2459989. ${ }^{28}$ Dashes indicate study not attempted. For replicates, mean \pm standard deviation is reported. All other values are $n=1$. All compounds were administered i.v. except for JDTic and nor-BNI (i.p.). JDTic and norBNI treated animals were administered radiotracer bolus and subseqent PET scan $30 \mathrm{~min}, 3 \mathrm{~h}$, and 25 days following drug treatment.

JDTic at 30 min pretreatment, animals were recurrently scanned at four additional time points $(3 \mathrm{~h}, 7$ days, 17 days, then 25 days following drug administration). Nor-BNI and JDTic caused a persistent decrease in $\left[{ }^{11} \mathrm{C}\right] \mathrm{GR} 103545 \mathrm{BP}_{\mathrm{ND}}$ up to 25 days after drug treatment (Table 1). This persistent decrease in $\mathrm{BP}_{\mathrm{ND}}$ was observed for both nor-BNI (high binding $\mathrm{BP}_{\mathrm{ND}}=16 \%$ of baseline) and JDTic (high binding $\mathrm{BP}_{\mathrm{ND}}=38 \%$ of baseline) 25 days after drug administration (Table 1 and Figure 4). These results were somewhat unexpected given that others have shown with ex vivo experiments in mice, KOR receptor density $\left(B_{\max }\right)$ and agonist affinity $\left(K_{\mathrm{d}}\right)$ were conserved following nor-BNI treatment. ${ }^{59}$ These ex vivo experiments were conducted with mouse brain membranes harvested 7 days after nor-BNI treatment $(10 \mathrm{mg} / \mathrm{kg}$, i.p. $)$, and incubated with $\left[{ }^{3} \mathrm{H}\right] \mathrm{U} 69,593$, so a direct comparison to our results is challenging. Additional in vivo PET studies with nor-BNI- or JDTic-treated animals need to be investigated to understand this phenomenon. Radiotracer administration paradigms such as bolus/infusion, ${ }^{63}$ followed by KOR agonist or antagonist drug challenge, could provide additional evidence on receptor availability toward certain
KOR pharmacophores. Taken together with our in vivo data as well as other reports on nor-BNI and JDTic mechanistic studies, ${ }^{59,61,62}$ these drugs impose sustained effects on KORmediated behavior, signaling, and radiotracer binding in vivo.

Blocking Studies with KOR Agonists. We had previously investigated salvinorin A occupancy with PET and failed to observe a dose-occupancy relationship with $\left[{ }^{11} \mathrm{C}\right] \mathrm{LY} 2795050$ or $\left[{ }^{11} \mathrm{C}\right] \mathrm{LY} 2459989$. While unexpected, this discrepancy has been reported for other GPCRs such as dopamine receptor. ${ }^{64}$ Given the wide chemical (structural) and pharmacological diversity of KOR targeting drugs that have been reported, and the two classes of KOR PET radiotracers available (phenylacetamide, KOR agonist; benzyloxyarylamide, KOR antagonist), we measured KOR agonist drug occupancy with $\left[{ }^{11} \mathrm{C}\right]$ GR103545 and compared results to $\left[{ }^{11} \mathrm{C}\right]$ LY2795050 and $\left[{ }^{11} \mathrm{C}\right]$ LY2459989 (Table 1). Butorphan (MCL-101) is a full agonist at KORs, derived from the morphinan class of opioids. ${ }^{65}$ Our results with morphinan KOR antagonists (i.e., naloxone, naltrexone) demonstrated complete blockade of radiotracer-specific binding, as anticipated. Butorphan was chosen because of its structural 

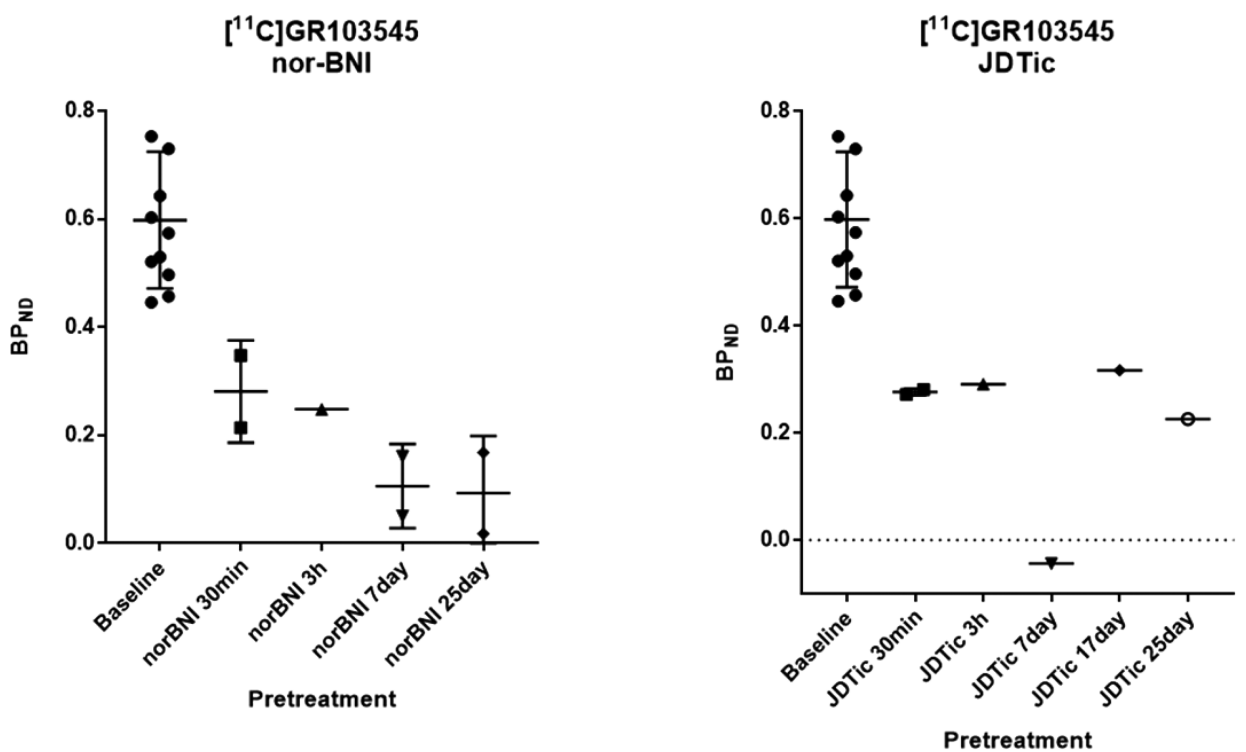

Figure 4. Longitudinal effects of nor-BNI and JDTic on $\left[{ }^{11} \mathrm{C}\right]$ GR103545 binding measured in vivo with PET. Sprague-Dawley rats were treated with JDTic or nor-BNI $(10 \mathrm{mg} / \mathrm{kg}$, i.p.) prior to radiotracer bolus. Following initial PET studies with nor-BNI and JDTic at 30 min pretreatment, animals were recurrently scanned at four additional time points ( $3 \mathrm{~h}, 7$ days, 17 days, then 25 days following drug administration). Both nor-BNI and JDTic caused a persistent decrease in $\left[{ }^{11} \mathrm{C}\right] \mathrm{GR} 103545 \mathrm{BP}_{\mathrm{ND}}$ up to 25 days after drug administration. $\mathrm{BP}_{\mathrm{ND}}$ listed represents average of high binding regions. Due to technical issues, nor-BNI-treated animals were not scanned on day 17.

similarity to naloxone and naltrexone, but has a different pharmacological effect (full agonist at KORs). Butorphan was administered to rats $(0.1 \mathrm{mg} / \mathrm{kg}$, i.v., 5 min pretreatment $)$ prior to $\left[{ }^{11} \mathrm{C}\right] \mathrm{LY} 2459989$ bolus. In high KOR density regions in the rat brain, $\left[{ }^{11} \mathrm{C}\right] \mathrm{LY} 2459989 \mathrm{BP}_{\mathrm{ND}}$ was reduced to $84 \%$ of baseline. At higher dose, $1 \mathrm{mg} / \mathrm{kg},\left[{ }^{11} \mathrm{C}\right] \mathrm{LY} 2459989 \mathrm{BP}_{\mathrm{ND}}$ was significantly reduced to $29 \%$ of baseline and was comparable to $\left[{ }^{11} \mathrm{C}\right]$ GR103545 $\mathrm{BP}_{\mathrm{ND}}$ (reduced to $34 \%$ of baseline from $1 \mathrm{mg} / \mathrm{kg}$ butorphan).

GR103545, (-)GR89696, is a potent full agonist at KORs $\left(K_{\mathrm{i}} 20 \mathrm{pM}, \mathrm{EC}_{50} 23 \mathrm{pM}\right)$ and belongs to the phenylacetamide class of KOR agonists. ${ }^{39}$ In our previous studies, we investigated $\left[{ }^{11} \mathrm{C}\right] \mathrm{GR} 103545 \mathrm{BP}_{\mathrm{ND}}$ changes following LY2795050 administration $(0.032$ and $0.32 \mathrm{mg} / \mathrm{kg}$, i.v., 5 min pretreatment). The inverse paradigm was also examined by administering racemic GR103545, ( \pm GR89696 (0.2 mg/kg, i.v.) followed by $\left[{ }^{11} \mathrm{C}\right] \mathrm{LY} 2459989$, which resulted in near complete block of radioligand binding $\left(\mathrm{BP}_{\mathrm{ND}} 21 \pm 4 \%, n=3\right)$. This indicates that both GR103545 and LY295050/LY2459989 can block each other's specific binding (Table 1).

$\mathrm{U}-50488$ is a potent full agonist at KORs $\left(K_{\mathrm{d}}=1.8 \mathrm{nM}\right)^{66}$ and a close structural analog of GR103545 (both drugs are dichlorophenylacetamides). U-50488, like many KOR agonists, produces analgesia in rodents and non-human primates, but in humans is dysphoric and aversive. ${ }^{38,67}$ Previous studies measuring U-50488 antinociception (paw pressure test) observed effects from 1 to $10 \mathrm{mg} / \mathrm{kg}$ (i.v.). ${ }^{67}$ In our experiments, we administered $( \pm) \mathrm{U}-50488(1 \mathrm{mg} / \mathrm{kg}$, i.v. $) 5 \mathrm{~min}$ prior to radiotracer bolus and measured changes in specific binding. At $1 \mathrm{mg} / \mathrm{kg}$, $\left[{ }^{11} \mathrm{C}\right]$ GR103545 $\mathrm{BP}_{\mathrm{ND}}$ in high binding region is significantly reduced to $19 \%$ of baseline. Surprisingly, the same pretreatment dose of $( \pm) \mathrm{U}-50488$ did not change $\left[{ }^{11} \mathrm{C}\right] \mathrm{LY} 2459989 \mathrm{BP}_{\mathrm{ND}}\left(\mathrm{BP}_{\mathrm{ND}}=\right.$ $95 \pm 17 \%$ of baseline, $n=2$ ) (Table 1 ).

Salvinorin A is a unique KOR agonist with rapid onset and short duration of action. ${ }^{68}$ A natural product derived from Salvia divinorum, this neoclerodane diterpene has high KOR affinity $\left(K_{\mathrm{i}}=1.3 \pm 0.5 \mathrm{nM}\right)^{69}$ and selectivity $(>10000: 1)$ over mu and delta opioid receptors. ${ }^{42}$ We previously reported the quantification of salvinorin A levels in the rat brain with $\left.{ }^{11} \mathrm{C}\right] \mathrm{GR} 103545 \mathrm{PET}^{46}$ This work was originally initiated with $\left[{ }^{11} \mathrm{C}\right]$ LY2795050, but we failed to see a change in binding potential relative to baseline scans. When salvinorin $\mathrm{A}$ is administered at moderate doses $(0.6 \mathrm{mg} / \mathrm{kg}$, i.v., $1 \mathrm{~min}$ pretreatment $)$ or high doses $(1.8 \mathrm{mg} / \mathrm{kg}$, i.v., $1 \mathrm{~min}$ pretreatment), $\left[{ }^{11} \mathrm{C}\right] \mathrm{GR} 103545 \mathrm{BP}_{\mathrm{ND}}$ is reduced to $63 \%$ and $26 \%$ of baseline, respectively (Table 1 ). Interestingly, at $0.6 \mathrm{mg} / \mathrm{kg}$, $\left[{ }^{11} \mathrm{C}\right] \mathrm{LY} 2459989 \mathrm{BP}_{\mathrm{ND}}$ does not change from baseline levels, and at $1.8 \mathrm{mg} / \mathrm{kg}$ only moderate changes in specific binding were observed $\left(\mathrm{BP}_{\mathrm{ND}}=75 \%\right.$ of baseline $)$. Consistently, $\left[{ }^{11} \mathrm{C}\right] \mathrm{LY} 2795050 \mathrm{BP}_{\mathrm{ND}}$ is only slightly reduced from $0.6 \mathrm{mg} / \mathrm{kg}$ $\left(\mathrm{BP}_{\mathrm{ND}}=93 \%\right.$ of baseline $)$ (Table 1$)$. Comparing dose-response curves for $\left[{ }^{11} \mathrm{C}\right] \mathrm{GR} 103545,\left[{ }^{11} \mathrm{C}\right] \mathrm{LY} 2459989$, and $\left[{ }^{11} \mathrm{C}\right]$ LY2795050 following salvinorin A administration (Figure 5), only $\left[{ }^{11} \mathrm{C}\right] \mathrm{GR} 103545$ results in a sigmoidal fit allowing estimation of $\mathrm{ED}_{50} \cdot\left[{ }^{11} \mathrm{C}\right] \mathrm{LY} 2795050 \mathrm{BP}_{\mathrm{ND}}$ was measured following six escalating doses of salvinorin A $(13,16,32,100$, $320,600 \mu \mathrm{g} / \mathrm{kg}$ ) all with little effect on specific binding. $\left[{ }^{11} \mathrm{C}\right] \mathrm{LY} 2459989 \mathrm{BP}_{\mathrm{ND}}$ was measured following moderate to high doses of salvinorin A $(560,600,1000,1800 \mu \mathrm{g} / \mathrm{kg})$ resulting in scattered effects with no apparent dose response (Figure 5).

This discrepancy in $\left[{ }^{11} \mathrm{C}\right] \mathrm{LY} 2795050$ and $\left[{ }^{11} \mathrm{C}\right] \mathrm{LY} 2459989$ binding is difficult to rationalize without extensive interrogation, but noncompetitive binding has been reported with other GPCRs in vitro ${ }^{70,71}$ and in vivo. ${ }^{52}$ One aspect that is important to discuss in these studies is the rate of dissociation for both drugs and radiotracers and the impact of pharmacokinetics on competitive binding. We have listed the pretreatment times used for each drug to allow for interpretation of direct or indirect competitive binding. While we fully understand that pretreatment timing and rates of dissociation will affect radiotracer binding, our pretreatment timing was consistent across both classes of radiotracers to allow comparison. For drugs that have rapid pharmacokinetics such as salvinorin $A$, a decrease in radioligand binding in vivo may be the result of both competitive 
$\left[{ }^{11} \mathrm{C}\right] \mathrm{GR} 103545$

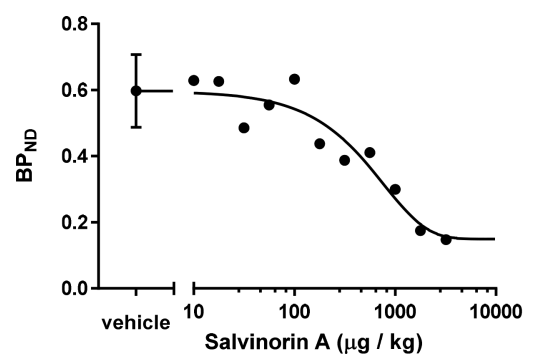

$\left[{ }^{11} \mathrm{C}\right] L Y 2459989$

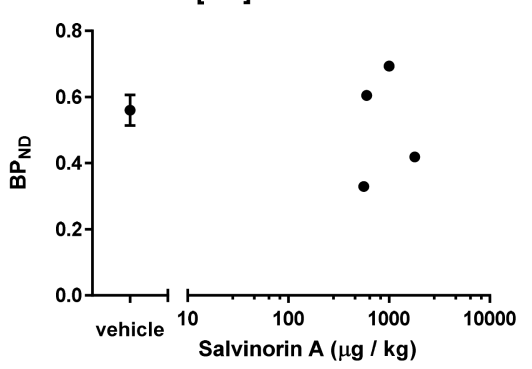

$\left[{ }^{11}\right.$ C]LY2795050

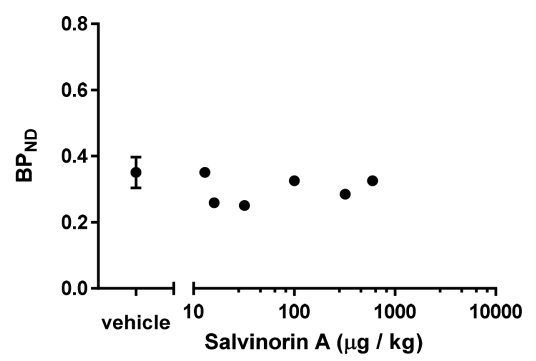

Figure 5. Salvinorin A dose-response PET experiments conducted in vivo with three different KOR radiotracers. Only [ $\left.{ }^{11} \mathrm{C}\right]$ GR 103545 showed decreased specific binding in a dose-dependent manner. $\mathrm{BP}_{\mathrm{ND}}$ 's represent data from high-binding ROIs. In all cases, salvinorin $\mathrm{A}$ was administered intravenously $1 \mathrm{~min}$ prior to radiotracer.

KOR wild type

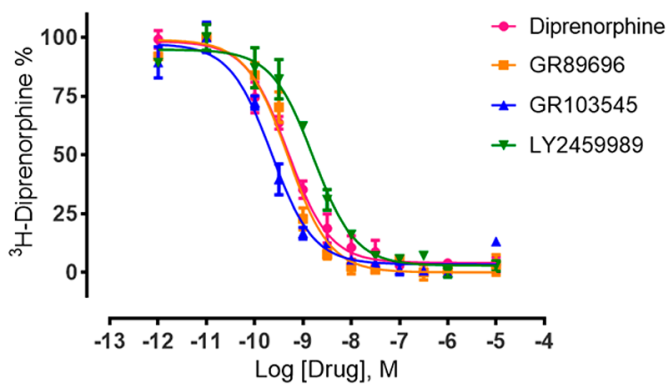

\begin{tabular}{ccccc}
\hline & Diprenorphine & GR89696 & GR103545 & LY2459989 \\
\hline Ki (KOR WT) & $1.603 \mathrm{e}-010$ & $1.601 \mathrm{e}-010$ & $7.405 \mathrm{e}-011$ & $5.412 \mathrm{e}-010$ \\
\hline
\end{tabular}
KOR D138N

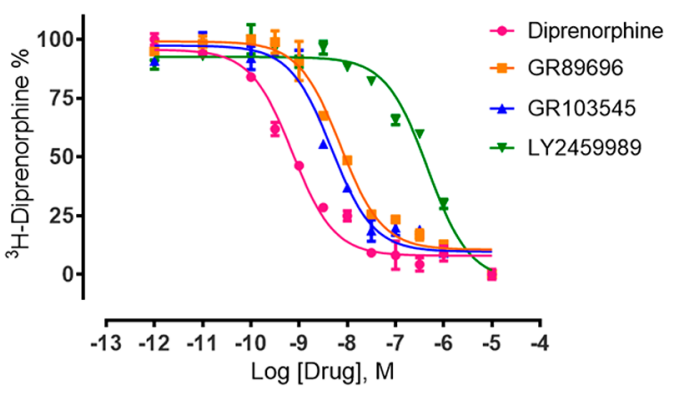

\begin{tabular}{lcccc}
\hline & Diprenorphine & GR89696 & GR103545 & LY2459989 \\
\hline Ki (KOR D138N) & $4.474 \mathrm{e}-010$ & $4.433 \mathrm{e}-009$ & $2.901 \mathrm{e}-009$ & $2.871 \mathrm{e}-007$ \\
\hline
\end{tabular}

Figure 6. In vitro radioligand binding studies in KOR wild-type and KOR mutant D138N with LY2459989, GR89696 (racemic GR103545), GR103545, and diprenorphine. When KOR is mutated at D138 in the active site, affinity was essentially lost for LY2459989 but not GR89696 or GR103545.

binding and receptor unavailability (i.e., receptor desensitization or internalization). In a previous report, we measured long-term effects of salvinorin A on $\left[{ }^{11} \mathrm{C}\right]$ GR103545 binding with PET by scanning minutes to hours after drug treatment. ${ }^{46}$ In rat, salvinorin A (i.v.) displays rapid uptake $\left(t_{\max }=13 \mathrm{~s}\right)$ and fast washout $\left(t_{1 / 2}=3.3 \mathrm{~min}\right)$, but we observed a persistent decrease in $\left[{ }^{11} \mathrm{C}\right] \mathrm{GR} 103545 \mathrm{BP}_{\mathrm{ND}}$ at $2.5 \mathrm{~h}$ pretreatment time, long after the drug had cleared from the brain. This indicates that at least $\left[{ }^{11} \mathrm{C}\right] \mathrm{GR} 103545$ is capable of measuring KOR availability following agonist drug clearance.

In addition, KOR structural biology has not fully elucidated receptor-ligand confirmations with all KOR pharmacophores. To date there are two KOR crystal structures: one solved with the antagonist JDTic, ${ }^{72}$ the other with the agonist MP-1104 and an active-state stabilizing nanobody. ${ }^{9}$ A comparison of the JDTic-bound conformation with the agonist state showed considerable differences in the overall shape of the binding pocket and conformations of key residues involved in binding and signaling. ${ }^{9}$ As the discrepancies in our studies were only observed with agonist drugs and antagonist radiotracers, it is important to remember that these two types of drugs stabilize distinct conformational ensembles.

Early attempts to understand KOR structure dynamics with agonists was performed with NMR experiments. The endogenous KOR ligand, dynorphin, bound to human KOR revealed there are multiple bound states of the peptide that result in a number of receptor conformations. ${ }^{11} \mathrm{~A}$ single model of dynorphin-KOR binding was not determined due to the observation of multiple conformers, all with similar energy. Instead, a few "poses" were described the first being KOR-1, defined as a representation of an inactive state of the receptor, which can still bind to the KOR antagonist JDTic. The conformation of KOR-2 correlates with an activated state and binds dynorphin with higher affinity. In a separate report, in silico docking studies on KOR binding with four structurally diverse agonists revealed multiple receptor conformations and binding modes. ${ }^{73}$ Also, the mutation of certain residues in the active site, altered binding of dynorphin $\mathrm{A}$ but not salvinorin $\mathrm{A}$ and U-69593. Further, docking studies with U-69593, U-50488, and salvinorin A indicated that these ligands bind to KORs in a unique way, leading to a unique KOR structure in the bound state. It is also conceivable that certain KOR PET radiotracers are only capable of binding to certain KOR conformations.

As already mentioned, we recently solved the KOR structure in its active state with the KOR agonist MP1104 (epoxy morphinan). ${ }^{74}$ Although several conformational differences were observed between the JDTic-KOR and MP1104-KOR structure, a key ligand-receptor contact was identified that had distinctive effects upon ligand binding when mutated, D138. When D138 in transmembrane helix 3 is mutated, dynorphin activity is abolished where as salvinorin A still maintains high affinity at KOR, likely due its lack of a basic nitrogen which is required for ligand-D138 interaction in agreement with prior studies. $^{75}$

In an effort to understand the binding differences between GR103545 and LY2459989, in vitro radioligand binding assays were carried out using KOR wild-type and a D138N mutant (Figure 6). In KOR WT, LY2459989 $K_{\mathrm{i}}$ was $0.54 \pm 0.04 \mathrm{nM}$ and GR103545 was $0.07 \mathrm{nM}$. In KOR D138N mutant, the binding of LY2459989 was dramatically compromised $\left(K_{\mathrm{i}}=287 \mathrm{nM} \pm 11\right.$; 
500-fold change); however, GR103545 still maintains high affinity $(2.9 \pm 0.2 \mathrm{nM})$ which indicates that $\mathrm{D} 138^{3.32}$ may not be necessary for its binding. (Figure 6). In addition, we measured affinity with conditions close to physiological environment (HEPES buffer $+100 \mathrm{mM} \mathrm{NaCl}$ ) but our results show a similar trend (SI, Figure S4). These data indicate LY2459989, and likely other aminobenzyloxyarylamides, recognizes and bind a receptor confirmation that is unique compared to other KOR pharmacophores.

Pharmacological PET imaging is an important tool for understanding drug-target engagement in the living brain. Over the past decade, PET imaging of KOR has been successful in validating two series of PET radiotracers. $\left[{ }^{11} \mathrm{C}\right] \mathrm{GR} 103545$ and $\left[{ }^{11} \mathrm{C}\right] /\left[{ }^{18} \mathrm{~F}\right] \mathrm{LY} 2459989$ have been evaluated in several species including humans, and used to measure occupancy of a few KOR antagonists in vivo with PET. Given that a large number of KOR pharmacophores exist, and the increasing interest in KOR therapeutics, it is important to understand any binding discrepancies for these two radiotracers with an array of KOR ligands. In rodents there is a tremendous opportunity to study KOR function with PET, in particular, using genetic or behavior models to help answer key neurobiological questions about the role of dynorphin and KORs in health disorders. This work highlights discrepancies we discovered during pharmacological PET studies in rats with $\left[{ }^{11} \mathrm{C}\right] \mathrm{GR} 103545,\left[{ }^{11} \mathrm{C}\right]$ LY2459989, and $\left[{ }^{11} \mathrm{C}\right]$ LY2795050. Given the active development of novel KOR ligand chemotypes and the potential of KOR therapeutics, we envision an increased need for KOR PET especially for measuring drug-target engagement in the human brain. A thorough evaluation of the tools available for KOR PET is important, as it is essential for understanding the considerations and discrepancies that may exist when measuring KOR drug occupancy in the living brain. Lastly, given the challenges with $\left[{ }^{11} \mathrm{C}\right]$ GR103545 human PET imaging (i.e., strict mass limit to avoid physiological effects, long scan times due to slow radiotracer kinetics), ${ }^{45}$ the development of improved KOR agonist PET radiotracers is needed.

\section{MATERIALS AND METHODS}

Materials. LY2795050 and radiolabeling precursor (corresponding aryl bromide) were synthesized according to methods previously reported. ${ }^{25,76}$ LY2459989 was synthesized according to methods previously reported. ${ }^{28}$ The synthesis of LY2459989 precursor (corresponding aryl bromide) is described in the SI. GR103545 standard and radiolabeling precursor (normethylcarbamoyl-GR103545) were purchased from ABX Chemical. JDTic (JDTic dihydrochloride) was supplied by F. Ivy Carroll and RTI International. Naloxone (naloxone hydrochloride dihydrate), U-50488 (( \pm )-trans-U-50488 methanesulfonate), naltrexone (naltrexone hydrochloride), nor-BNI (nor-binaltorphimine dihydrochloride), and butorphan (butorphan $S$-(+)-mandelate) were purchased from Sigma-Aldrich (St. Louis, MO). Reagents and solvents were purchased from Sigma-Aldrich (St. Louis, MO) and used without further treatment unless specified. Tetrakis(triphenylphosphine)palladium $(0)$ was purchased from Strem Chemicals (Newburyport, MA). For palladium-catalyzed cyanation, anhydrous dimethyl sulfoxide was purchased form Sigma-Aldrich (St. Louis, MO) and sparged with nitrogen prior to use.

Radiochemistry. Radioactivity was produced by an Eclipse HP 11 $\mathrm{MeV}$ cyclotron (Siemens Healthcare, Munich, Germany) using a ${ }^{11} \mathrm{C}$ gas target $\left(\mathrm{N}_{2}\right.$ gas containing $\left.2.5 \% \mathrm{O}_{2}\right)$ irradiated at $52 \mu \mathrm{A}$ to produce ${ }^{11} \mathrm{C}-\mathrm{CO}_{2}$. HPLC purification of radiotracers was performed with an Agilent 1200 series HPLC equipped with a diode array detector, Carroll \& Ramsey radiation detector (Model 105S), quaternary pump, and a Vici injector port equipped with a $2 \mathrm{~mL}$ sample loop. Microwave chemistry was performed with a Resonance Instruments Inc. microwave reactor, Model 521 (Skokie, IL, USA). Purified, formulated radiotracers were analyzed by analytical HPLC to measure radiochemical purity ( $\geq 98 \%)$, specific activity, and identity was confirmed by co-injection with the appropriate ${ }^{12} \mathrm{C}$-standard. $\mathrm{EOS}=$ end of synthesis (final formulation); $\mathrm{NDC}=$ nondecay-corrected; $\mathrm{EOB}=$ end of beam.

$\left[{ }^{11} \mathrm{C}\right] L Y 2459989$ Radiosynthesis. ${ }^{11} \mathrm{C}-\mathrm{CO}_{2}$ was delivered to a Siemens Healthcare Explora $\mathrm{CN}$ synthesis module with helium as a carrier. ${ }^{11} \mathrm{C}-\mathrm{CO}_{2}$ was converted to ${ }^{11} \mathrm{C}_{-} \mathrm{CH}_{4}$ with $\mathrm{H}_{2}$ on nickel at $400{ }^{\circ} \mathrm{C}$, and then to ${ }^{11} \mathrm{C}-\mathrm{HCN}$ with $\mathrm{NH}_{3}$ on platinum at $900{ }^{\circ} \mathrm{C}$. ${ }^{11} \mathrm{C}$ $\mathrm{HCN}$ was bubbled at 12 psi directly into the $5 \mathrm{~mL} \mathrm{v}$-vial containing the precursor (S)-3-(1-(4-(4-bromo-2-fluorophenoxy)benzyl)pyrrolidin2-yl)pyridine) (1.0 mg), $\mathrm{Pd}\left(\mathrm{PPh}_{3}\right)_{4}(1.2 \mathrm{mg})$, and $\mathrm{K}_{2} \mathrm{CO}_{3}(1.0 \mathrm{mg})$, in DMSO $(0.5 \mathrm{~mL})$ at room temperature. When radioactivity peaked, the reaction vial was subjected to microwave heating with stirring $(80 \mathrm{~W}, 25 \mathrm{~s})$. The reaction was allowed to cool for $1 \mathrm{~min}$ before $\mathrm{H}_{2} \mathrm{O}_{2}$ $(10 \%, 150 \mu \mathrm{L})$ was added, and the mixture was allowed to stir at room temperature for $2 \mathrm{~min}$. The mixture was diluted with mobile phase $(1.3 \mathrm{~mL})$ and purified by semipreparative HPLC $(9.4 \times 250 \mathrm{~mm}$ Agilent Eclipse XDB-C18, $5 \mu \mathrm{m}$ ) with ACN: $\mathrm{H}_{2} \mathrm{O}: \mathrm{TFA}$ (17\%: 82.9\%: $0.1 \%)$ at $5 \mathrm{~mL} / \mathrm{min}$. The product eluted at approximately $9 \mathrm{~min}$ and was diluted with water $(20 \mathrm{~mL})$, passed through a Sep Pak (C-18 plus, conditioned with $1 \mathrm{~mL}$ ethanol followed by $10 \mathrm{~mL}$ water). The Sep Pak was washed with sterile water $(5 \mathrm{~mL})$, and the final product was reverse eluted with ethanol $(1 \mathrm{~mL})$ and diluted with saline $(9 \mathrm{~mL})$. The formulated product was passed through a sterile filter $(0.45 \mu \mathrm{m})$ into a sterile vial ready for injection. $\left[{ }^{11} \mathrm{C}\right] \mathrm{LY} 2459989$ was synthesized with an average RCY of $29 \pm 10 \%$ (EOS, NDC), average synthesis time of $30 \mathrm{~min}$ from $\mathrm{EOB}$, and an average specific activity of $2.7 \pm 1.4 \mathrm{mCi} / \mathrm{nmol}$ at EOS.

$\left[{ }^{11} \mathrm{C}\right]$ LY2795050 Radiosynthesis. $\left[{ }^{11} \mathrm{C}\right] \mathrm{LY} 2795050$ radiosynthesis was conducted with conditions identical to $\left[{ }^{11} \mathrm{C}\right]$ LY2459989. Purification of the crude reaction was performed on semipreparative HPLC $(9.4 \times 250 \mathrm{~mm}$ Agilent Eclipse XDB-C18, $5 \mu \mathrm{m})$ with ACN: $\mathrm{H}_{2} \mathrm{O}$ :TFA (20\%: 79.9\%: 0.1\%) at $5 \mathrm{~mL} / \mathrm{min}$. The product eluted at approximately $7 \mathrm{~min}$ and was diluted with water $(20 \mathrm{~mL})$, passed through a Sep Pak (C-18 plus, conditioned with $1 \mathrm{~mL}$ ethanol followed by $20 \mathrm{~mL}$ water). The Sep Pak was washed with sterile water $(5 \mathrm{~mL})$, and the final product was reverse eluted with ethanol $(1 \mathrm{~mL})$ and diluted with saline $(9 \mathrm{~mL})$. The formulated product was passed through a sterile filter $(0.45 \mu \mathrm{m})$ into a sterile vial ready for injection. $\left[{ }^{11} \mathrm{C}\right]$ LY2795050 was synthesized with an average RCY of $21 \pm 8 \%$ (EOS, NDC), average synthesis time of $30 \mathrm{~min}$ from $\mathrm{EOB}$, and an average specific activity of $2.5 \pm 0.9 \mathrm{mCi} / \mathrm{nmol}$ at EOS.

$\left[{ }^{11} \mathrm{C}\right] \mathrm{GR} 103545$ was synthesized and purified according to methods identical to those previously published, with an average RCY of $15.2 \pm 6.1 \%$ (EOS, NDC) and an average specific activity of $6.9 \pm 2.2 \mathrm{mCi} / \mathrm{nmol}$ at EOS.

Rodent PET and Image Analysis. Male Sprague-Dawley rats were anesthetized with isoflurane (3\% isoflurane for induction, $1.5 \%$ for maintenance) with oxygen as a carrier. Rats were catheterized in a lateral tail vein, connected to an extension line primed with heparinized saline $(0.9 \%)$, and placed in a head-first prone position on scanner bed. For blocking experiments, animals received either a bolus i.v. injection of drug or vehicle prior to administration of the radiotracer. All compounds were administered intravenously except for JDTic and nor$\mathrm{BNI}$ (intraperitoneal). Compounds were formulated for injection as follows: Salvinorin A (3:3:14 DMSO:Tween80:saline), LY2795050 (1:1:8 DMSO:Tween80:saline), U-50488 (saline), GR89696 (saline), naloxone (saline), naltrexone (saline), butorphan (saline), nor-BNI (saline), JDTic (saline). All formulations were diluted appropriately to administer $2 \mathrm{~mL} / \mathrm{kg}$. $\left[{ }^{11} \mathrm{C}\right] \mathrm{GR} 103545,\left[{ }^{11} \mathrm{C}\right] \mathrm{LY} 2795050$, and $\left[{ }^{11} \mathrm{C}\right]$ LY2459989 were formulated in $10 \%$ ethanol/90\% saline and administered intravenously (bolus, $0.7 \pm 0.2 \mathrm{mCi}$ ) following vehicle or drug challenge. Rodents underwent a $60 \mathrm{~min}$ dynamic PET scan followed by a CT scan for attenuation and co-registration. Images were reconstructed using an iterative MLEM (maximum likelihood expectation maximization) algorithm, and the data were binned into 32 frames $(8 \times 15 \mathrm{~s}, 8 \times 1 \mathrm{~min}, 10 \times 2 \mathrm{~min}, 6 \times 5 \mathrm{~min})$. Raw images were processed using PMOD 3.3 (PMOD Technologies, Zurich, Switzerland). Co-registered PET/CT images were spatially aligned to the Schiffer rat brain template (Px Rat), ${ }^{77}$ and regional time-activity curves 
were generated. Specific binding with respect to displaceable uptake $\left(\mathrm{BP}_{\mathrm{ND}}\right)$ was calculated using the Logan reference analysis method with cerebellum as reference region, $\left[{ }^{11} \mathrm{C}\right] \mathrm{GR} 103545 t^{*}=20 \mathrm{~min}$, $\left[{ }^{11} \mathrm{C}\right] \mathrm{LY} 2459989 t^{*}=30 \mathrm{~min},\left[{ }^{11} \mathrm{C}\right] \mathrm{LY} 2795050 t^{*}=30 \mathrm{~min}^{78-80}$

Nor-BNI and JDTic Longitudinal PET Study. Following initial $\left[{ }^{11} \mathrm{C}\right]$ GR103545 PET studies with nor-BNI and JDTic (30 min pretreatment), animals were recurrently scanned at four additional time points ( 3 h, 7 days, 17 days, then 25 days following drug administration). After completion of the first scan (30 min time point), animals were removed from isoflurane and returned to holding cages. At approximately $2.5 \mathrm{~h}$, animals were anesthetized again with isoflurane (3\% for induction, $1.5 \%$ for maintenance) and injected with $\left[{ }^{11} \mathrm{C}\right] \mathrm{GR} 103545$ bolus at $3 \mathrm{~h}$ from initial drug administration. Upon completion of this second scan ( $3 \mathrm{~h}$ time point), animals were returned to holding cages until next $\left[{ }^{11} \mathrm{C}\right]$ GR103545 PET scan on day 7, day 17 , or day 25. Due to technical issues, nor-BNI-treated animals were not scanned on day 17. Scan parameters, data reconstruction, and analysis methods were identical to those described above.

Radioligand Binding Assays. Binding assays were performed using HEK293 T membrane preparations transiently expressing KOR wild type or D138N mutant. Binding assays were set up in 96-well plates in the standard binding buffer ( $50 \mathrm{mM}$ Tris, $0.1 \mathrm{mM}$ EDTA, $10 \mathrm{mM}$ $\mathrm{MgCl}_{2}, 0.1 \%$ BSA, $\mathrm{pH} 7.4$ ) or HEPES buffer (25 mM HEPES, $100 \mathrm{mM}$ $\mathrm{NaCl}, \mathrm{pH} 7.4$ ) (SI, Figure S4). For the competition binding, $50 \mu \mathrm{L}$ each of ${ }^{3} \mathrm{H}$-diprenorphine (final $0.81 \mathrm{nM}$ ), drug solution $(3 \times)$, and homogeneous membrane solution was incubated in 96-well plate in the standard binding buffer. Reactions were incubated for $2 \mathrm{~h}$ at room temperature in the dark, terminated by rapid vacuum filtration onto chilled 0.3\% PEI-soaked GF/A filters followed by three quick washes with cold washing buffer $(50 \mathrm{mM}$ Tris $\mathrm{HCl}, \mathrm{pH} 7.40)$, and read. Results (with or without normalization) were analyzed using GraphPad Prism 5.0 using "one site-fit Ki" model.

\section{ASSOCIATED CONTENT}

\section{S Supporting Information}

The Supporting Information is available free of charge on the ACS Publications website at DOI: 10.1021/acschemneuro.8b00293.

Details for the synthesis of LY2459989-precursor (aryl bromide) and baseline time activity curves for $\left[{ }^{11} \mathrm{C}\right]$ GR103545, $\left[{ }^{11} \mathrm{C}\right] \mathrm{LY} 2795050$, and $\left[{ }^{11} \mathrm{C}\right] \mathrm{LY} 2459989$; results from in vitro radioligand binding assays conducted with or without the presence of sodium in buffer (PDF)

\section{AUTHOR INFORMATION}

\section{Corresponding Authors}

*E-mail: michael.placzek@mgh.harvard.edu.

*E-mail: hooker@nmr.mgh.harvard.edu.

\section{ORCID $\odot$}

Michael S. Placzek: 0000-0002-5224-6024

Frederick A. Schroeder: 0000-0003-0469-4196

Bryan L. Roth: 0000-0002-0561-6520

Jacob M. Hooker: 0000-0002-9394-7708

\section{Author Contributions}

M.S.P. and J.M.H. designed experiments and managed the execution of this project. M.S.P., R.N., and C.W. synthesized nonradioactive compounds and PET radiotracers for these experiments. M.S.P. and F.A.S. conducted rodent PET imaging experiments. M.S.P. and H.-Y.W. analyzed PET data and kinetic modeling. T.C. and B.L.R. designed and performed in vitro binding experiments. M.S.P. wrote the manuscript with help from all authors.

\section{Funding}

This work was supported by the Athinoula A. Martinos Center for Biomedical Imaging at Massachusetts General Hospital, using resources provided by the Center for Functional Neuroimaging Technologies, P41EB015896, a P41 Biotechnology Resource Grant supported by the National Institute of Biomedical Imaging and Bioengineering (NIBIB), National Institutes of Health. This work also involved the use of instrumentation supported by the NIH Shared Instrumentation Grant Program and/or High-End Instrumentation Grant Program; specifically, grant number(s) S10RR015728, S10RR026666, and S10RR017208, P41RR14075. This work was also made possible by the following funding: MGH ECOR Scholars Program 2016A050771, NIH-NIDA T32DA015036, and NIH-NIDA K99DA037928.

\section{Notes}

The authors declare no competing financial interest.

\section{ACKNOWLEDGMENTS}

The authors thank Judit Sore and the radiopharmacy at the Martinos Center for their assistance with PET radiotracer synthesis. We thank Aijun Zhu, Genevieve Van de Bittner, and Martin Strebl for their assistance with animal preparation and scanner operation. We would also like to thank F. Ivy Carroll for supplying JDTic for these studies.

\section{REFERENCES}

(1) Lord, J. A. H., Waterfield, A. A., Hughes, J., and Kosterlitz, H. W. (1977) Endogenous opioid peptides: Multiple agonists and receptors. Nature 267, 495-499.

(2) Evans, C., Keith, D., Morrison, H., Magendzo, K., and Edwards, R. (1992) Cloning of a delta opioid receptor by functional expression. Science (Washington, DC, U. S.) 258, 1952-1955.

(3) Chen, Y., Chen, Y., Mestek, A., Mestek, A., Liu, J., Liu, J., Hurley, J. A., Hurley, J. A., Yu, L., and Yu, L. (1993) Molecular cloning and functional expression of a mu-opioid receptor from rat brain. Mol. Pharmacol. 44, 8-12.

(4) Minami, M., Toya, T., Katao, Y., Maekawa, K., Nakamura, S., Onogi, T., Kaneko, S., and Satoh, M. (1993) Cloning and expression of a cDNA for the rat k-opioid receptor. FEBS Lett. 329, 291-295.

(5) Schwarzer, C. (2009) 30 years of dynorphins - New insights on their functions in neuropsychiatric diseases. Pharmacol. Ther. 123, 353-370.

(6) Simonin, F., Gavériaux-Ruff, C., Befort, K., Matthes, H., Lannes, B., Micheletti, G., Mattéi, M. G., Charron, G., Bloch, B., and Kieffer, B. (1995) kappa-Opioid receptor in humans: cDNA and genomic cloning, chromosomal assignment, functional expression, pharmacology, and expression pattern in the central nervous system. Proc. Natl. Acad. Sci. U. S. A. 92, 7006-10.

(7) Crowley, N. A., and Kash, T. L. (2015) Kappa opioid receptor signaling in the brain: Circuitry and implications for treatment. Prog. Neuro-Psychopharmacol. Biol. Psychiatry 62, 51-60.

(8) Béguin, C., and Cohen, B. M. (2009) Medicinal Chemistry of Kappa Opioid Receptor Antagonists BT - Opiate Receptors and Antagonists, Opiate Receptors and Antagonists, pp 99-118, Humana Press, Totowa, NJ.

(9) Che, T., Majumdar, S., Zaidi, S. A., Ondachi, P., McCorvy, J. D., Wang, S., Mosier, P. D., Uprety, R., Vardy, E., Krumm, B. E., Han, G. W., Lee, M. Y., Pardon, E., Steyaert, J., Huang, X. P., Strachan, R. T., Tribo, A. R., Pasternak, G. W., Carroll, F. I., Stevens, R. C., Cherezov, V., Katritch, V., Wacker, D., and Roth, B. L. (2018) Structure of the Nanobody-Stabilized Active State of the Kappa Opioid Receptor. Cell 172, 55-67.e15.

(10) Chavkin, C., James, I. F., and Goldstein, A. (1982) Dynorphin is a specific endogenous ligand of the kappa opioid receptor. Science 215, $413-5$.

(11) O'Connor, C., White, K. L., Doncescu, N., Didenko, T., Roth, B. L., Czaplicki, G., Stevens, R. C., Wüthrich, K., and Milon, A. (2015) NMR structure and dynamics of the agonist dynorphin peptide bound 
to the human kappa opioid receptor. Proc. Natl. Acad. Sci. U. S. A. 112, $11852-11857$.

(12) Kivell, B., and Prisinzano, T. E. (2010) Kappa opioids and the modulation of pain. Psychopharmacology (Berl) 210, 109-119.

(13) Kumor, K. M., Haertzen, C. A., Johnson, R. E., Kocher, T., and Jasinski, D. (1986) Human psychopharmacology of ketocyclazocine as compared with cyclazocine, morphine and placebo. J. Pharmacol. Exp. Ther. 238, 960-968.

(14) Pfeiffer, A., Brantl, V., Herz, A., and Emrich, H. M. (1986) Psychotomimesis mediated by kappa opiate receptors. Science 233, 774-6.

(15) Bohn, L. M., and Aube, J. Seeking (and Finding) Biased Ligands of the Kappa Opioid Receptor.

(16) Zheng, Z., Huang, X. P., Mangano, T. J., Zou, R., Chen, X., Zaidi, S. A., Roth, B. L., Stevens, R. C., and Katritch, V. (2017) StructureBased Discovery of New Antagonist and Biased Agonist Chemotypes for the Kappa Opioid Receptor. J. Med. Chem. 60, 3070-3081.

(17) Luttrell, L. M., Maudsley, S., and Bohn, L. M. (2015) Fulfilling the Promise of "Biased" G Protein-Coupled Receptor Agonism. Mol. Pharmacol. 88, 579-588.

(18) Whalen, E. J., Rajagopal, S., and Lefkowitz, R. J. (2011) Therapeutic potential of $\beta$-arrestin- and $\mathrm{G}$ protein-biased agonists. Trends Mol. Med. 17, 126-139.

(19) White, K. L., Robinson, J. E., Zhu, H., DiBerto, J. F., Polepally, P. R., Zjawiony, J. K., Nichols, D. E., Malanga, C. J., and Roth, B. L. (2015) The G Protein-Biased -Opioid Receptor Agonist RB-64 Is Analgesic with a Unique Spectrum of Activities In Vivo. J. Pharmacol. Exp. Ther. $352,98-109$.

(20) Brust, T. F., Morgenweck, J., Kim, S. A., Rose, J. H., Locke, J. L., Schmid, C. L., Zhou, L., Stahl, E. L., Cameron, M. D., Scarry, S. M., Aubé, J., Jones, S. R., Martin, T. J., and Bohn, L. M. (2016) Biased agonists of the kappa opioid receptor suppress pain and itch without causing sedation or dysphoria. Sci. Signaling 9, ra117.

(21) Spetea, M., Eans, S. O., Ganno, M. L., Lantero, A., Mairegger, M., Toll, L., Schmidhammer, H., and McLaughlin, J. P. (2017) Selective $\kappa$ receptor partial agonist HS666 produces potent antinociception without inducing aversion after i.c.v. administration in mice. $\mathrm{Br}$. $\mathrm{J}$. Pharmacol. 174, 2444-2456.

(22) Buda, J. J., Carroll, F. I., Kosten, T. R., Swearingen, D., and Walters, B. B. (2015) A Double-Blind, Placebo-Controlled Trial to Evaluate the Safety, Tolerability, and Pharmacokinetics of Single, Escalating Oral Doses of JDTic. Neuropsychopharmacology 40, 20592065.

(23) Li, W., Sun, H., Chen, H., Yang, X., Xiao, L., Liu, R., Shao, L., and Qiu, Z. (2016) Major Depressive Disorder and Kappa Opioid Receptor Antagonists. Transl. Perioper. Pain Med. 3, 4-16.

(24) Helal, M. A., Habib, E. S., and Chittiboyina, A. G. (2017) Selective kappa opioid antagonists for treatment of addiction, are we there yet? Eur. J. Med. Chem. 141, 632-647.

(25) Mitch, C. H., Quimby, S. J., Diaz, N., Pedregal, C., de la Torre, M. G., Jimenez, A., Shi, Q., Canada, E. J., Kahl, S. D., Statnick, M. a., Mckinzie, D. L., Benesh, D. R., Rash, K. S., and Barth, V. N. (2011) Discovery of Aminobenzyloxyarylamides as $j$ Opioid Receptor Selective Antagonists : Application to Preclinical Development of a j Opioid Receptor Antagonist Receptor Occupancy Tracer. J. Med. Chem. 54, $8000-8012$.

(26) Lowe, S. L., Wong, C. J., Witcher, J., Gonzales, C. R., Dickinson, G. L., Bell, R. L., Rorick-Kehn, L., Weller, M., Stoltz, R. R., Royalty, J., and Tauscher-Wisniewski, S. (2014) Safety, tolerability, and pharmacokinetic evaluation of single- and multiple-ascending doses of a novel kappa opioid receptor antagonist LY2456302 and drug interaction with ethanol in healthy subjects. J. Clin. Pharmacol. 54, 968978.

(27) Zheng, M. Q., Nabulsi, N., Kim, S. J., Tomasi, G., Lin, S. F., Mitch, C., Quimby, S., Barth, V., Rash, K., Masters, J., Navarro, a., Seest, E., Morris, E. D., Carson, R. E., and Huang, Y. (2013) Synthesis and evaluation of 11C-LY2795050 as a kappa-opioid receptor antagonist radiotracer for PET imaging. J. Nucl. Med. 54, 455-463.
(28) Zheng, M.-Q., Kim, S. J., Holden, D., Lin, S. -f., Need, A., Rash, K., Barth, V., Mitch, C., Navarro, A., Kapinos, M., Maloney, K., Ropchan, J., Carson, R. E., and Huang, Y. (2014) An Improved Antagonist Radiotracer for the -Opioid Receptor: Synthesis and Characterization of 11C-LY2459989. J. Nucl. Med. 55, 1185-1191.

(29) Li, S., Cai, Z., Zheng, M.-Q., Holden, D., Naganawa, M., Lin, S.F., Ropchan, J., Labaree, D., Kapinos, M., Lara-Jaime, T., Navarro, A., and Huang, Y. (2018) Novel 18F-Labeled $\kappa$-Opioid Receptor Antagonist as PET Radiotracer: Synthesis and In Vivo Evaluation of 18F-LY2459989 in Nonhuman Primates. J. Nucl. Med. 59, 140-146.

(30) Urbano, M., Guerrero, M., Rosen, H., and Roberts, E. (2014) Antagonists of the kappa opioid receptor. Bioorg. Med. Chem. Lett. 24, 2021-2032.

(31) Carroll, F. I., and Carlezon, W. A. (2013) Development of Kappa Opioid Receptor Antagonists. J. Med. Chem. 56, 2178-2195.

(32) Portoghese, P. S., Lipkowski, A. W., and Takemori, A. E. (1987) Binaltorphimine and nor-binaltorphimine, potent and selective $\mathrm{k}$ opioid receptor antagonists. Life Sci. 40, 1287-1292.

(33) Takemori, A., Begonia, Y., Naeseth, S., and Portoghese, P. S. (1988) Nor-Binaltorphimine, a Highly Selective Kappa-Opioid in Analgesic and Receptor Binding Assays. J. Pharmacol. Exp. Ther. 246, 255-258.

(34) Patkar, K. A., Wu, J., Ganno, M. L., Singh, H. D., Ross, N. C., Rasakham, K., Toll, L., and McLaughlin, J. P. (2013) Physical Presence of Nor-Binaltorphimine in Mouse Brain over 21 Days after a Single Administration Corresponds to Its Long-Lasting Antagonistic Effect on -Opioid Receptors. J. Pharmacol. Exp. Ther. 346, 545-554.

(35) VonVoigtlander, P. F., Lahti, R. A., and Ludens, J. H. (1983) U50,488: a selective and structurally novel non-Mu (kappa) opioid agonist. J. Pharmacol. Exp. Ther. 224, 7-12.

(36) McLaughlin, J. P., Land, B. B., Li, S., Pintar, J. E., and Chavkin, C. (2006) Prior activation of kappa opioid receptors by U50,488 mimics repeated forced swim stress to potentiate cocaine place preference conditioning. Neuropsychopharmacology 31, 787-794.

(37) Xia, Q., Sheng, J. Z., Tai, K. K., and Wong, T. M. (1994) Effects of chronic U50,488H treatment on binding and mechanical responses of the rat hearts. J. Pharmacol. Exp. Ther. 268, 930-934.

(38) France, C. P., Medzihradsky, F., and Woods, J. H. (1994) Comparison of kappa opioids in rhesus monkeys: behavioral effects and receptor binding affinities. J. Pharmacol. Exp. Ther. 268, 47-58.

(39) Naylor, A., Judd, D. B., Lloyd, J. E., Scopes, D. I. C., Hayes, A. G., and Birch, P. J. (1993) A Potent New Class of $\kappa$-Receptor Agonist: 4Substituted 1-(Arylacetyl)-2-[(dialkylamino)methyl]piperazines. J. Med. Chem. 36, 2075-2083.

(40) Ravert, H. T., Scheffel, U., Mathews, W. B., Musachio, J. L., and Dannals, R. F. (2002) [11C]-GR89696, a potent kappa opiate receptor radioligand; in vivo binding of the R and S enantiomers. Nucl. Med. Biol. $29,47-53$.

(41) Talbot, P. S., Narendran, R., Butelman, E. R., Huang, Y., Ngo, K., Slifstein, M., Martinez, D., Laruelle, M., and Hwang, D.-R. (2005) 11CGR103545, a radiotracer for imaging kappa-opioid receptors in vivo with PET: synthesis and evaluation in baboons. J. Nucl. Med. 46, 484494.

(42) Roth, B. L., Baner, K., Westkaemper, R., Siebert, D., Rice, K. C., Steinberg, S., Ernsberger, P., and Rothman, R. B. (2002) Salvinorin A: A potent naturally occurring nonnitrogenous opioid selective agonist. Proc. Natl. Acad. Sci. U. S. A. 99, 11934-11939.

(43) Gupta, A., Gomes, I., Bobeck, E. N., Fakira, A. K., Massaro, N. P., Sharma, I., Cavé, A., Hamm, H. E., Parello, J., and Devi, L. A. (2016) Collybolide is a novel biased agonist of $\kappa$-opioid receptors with potent antipruritic activity. Proc. Natl. Acad. Sci. U. S. A. 113, 6041-6046.

(44) Cunningham, C. W., Rothman, R. B., and Prisinzano, T. E. (2011) Neuropharmacology of the Naturally Occurring k-Opioid Hallucinogen Salvinorin A. Pharmacol. Rev. 63, 316-347.

(45) Naganawa, M., Jacobsen, L. K., Zheng, M.-Q., Lin, S.-F., Banerjee, A., Byon, W., Weinzimmer, D., Tomasi, G., Nabulsi, N., Grimwood, S., Badura, L. L., Carson, R. E., McCarthy, T. J., and Huang, Y. (2014) Evaluation of the agonist PET radioligand [11C]GR103545 to image kappa opioid receptor in humans: Kinetic model selection, 
test-retest reproducibility and receptor occupancy by the antagonist PF-04455242. NeuroImage 99, 69-79.

(46) Placzek, M. S., Van De Bittner, G. C., Wey, H. Y., Lukas, S. E., and Hooker, J. M. (2015) Immediate and persistent effects of salvinorin A on the kappa opioid receptor in rodents, monitored in vivo with PET. Neuropsychopharmacology 40, 2865-2872.

(47) Kim, S. J., Zheng, M.-Q., Nabulsi, N., Labaree, D., Ropchan, J., Najafzadeh, S., Carson, R. E., Huang, Y., and Morris, E. D. (2013) Determination of the In Vivo Selectivity of a New -Opioid Receptor Antagonist PET Tracer 11C-LY2795050 in the Rhesus Monkey. J. Nucl. Med. 54, 1668-1674.

(48) Naganawa, M., Zheng, M. Q., Nabulsi, N., Tomasi, G., Henry, S., Lin, S. F., Ropchan, J., Labaree, D., Tauscher, J., Neumeister, A., Carson, R. E., and Huang, Y. (2014) Kinetic modeling of 11 CLY2795050, a novel antagonist radiotracer for PET imaging of the kappa opioid receptor in humans. J. Cereb. Blood Flow Metab. 34, 18181825.

(49) Naganawa, M., Dickinson, G. L., Zheng, M.-Q., Henry, S., Vandenhende, F., Witcher, J., Bell, R., Nabulsi, N., Lin, S.-F., Ropchan, J., Neumeister, A., Ranganathan, M., Tauscher, J., Huang, Y., and Carson, R. E. (2016) Receptor Occupancy of the $\kappa$-Opioid Antagonist LY2456302 Measured with Positron Emission Tomography and the Novel Radiotracer 11C-LY2795050. J. Pharmacol. Exp. Ther. 356, 2606.

(50) White, K. L., Scopton, A. P., Rives, M.-L., Bikbulatov, R. V., Polepally, P. R., Brown, P. J., Kenakin, T., Javitch, J. A., Zjawiony, J. K., and Roth, B. L. (2014) Identification of Novel Functionally Selective -Opioid Receptor Scaffolds. Mol. Pharmacol. 85, 83-90.

(51) Bruchas, M. R., and Roth, B. L. (2016) New Technologies for Elucidating Opioid Receptor Function. Trends Pharmacol. Sci. 37, 279289.

(52) Laruelle, M. (2000) Imaging Synaptic Neurotransmission with in Vivo Binding Competition Techniques: A Critical Review. J. Cereb. Blood Flow Metab. 20, 423-451.

(53) Wey, H.-Y., Placzek, M. S., Hooker, J. M., Mandeville, J. B., and Rosen, B. R. (2017) Measure and Validate Agonist-Induced mu-Opioid Receptor Desensitization Using Simultaneous PET/MRI. Neuropsychopharmacology, S622-S623.

(54) Nock, B., Rajpara, A., O'Connor, L. H., and Cicero, T. J. (1988) Autoradiography of $[3 \mathrm{H}] \mathrm{U}-69593$ binding sites in rat brain: evidence for $\kappa$ opioid receptor subtypes. Eur. J. Pharmacol. 154, 27-34.

(55) Mansour, A., Khachaturian, H., Lewis, M. E., Akil, H., and Watson, S. J. (1988) Anatomy of CNS opioid receptors. Trends Neurosci. 11, 308-314.

(56) Unterwald, E. M., Knapp, C., and Zukin, R. S. (1991) Neuroanatomical localization of kappa 1 and kappa 2 opioid receptors in rat and guinea pig brain. Brain Res. 562, 57-65.

(57) Mansour, A., Khachaturian, H., Lewis, M. E., Akil, H., and Watson, S. J. (1987) Autoradiographic differentiation of mu, delta, and kappa opioid receptors in the rat forebrain and midbrain. J. Neurosci. 7, 2445-2464.

(58) Carroll, I., Thomas, J. B., Dykstra, L. A., Granger, A. L., Allen, R. M., Howard, J. L., Pollard, G. T., Aceto, M. D., and Harris, L. S. (2004) Pharmacological properties of JDTic: A novel $\kappa$-opioid receptor antagonist. Eur. J. Pharmacol. 501, 111-119.

(59) Bruchas, M. R., Yang, T., Schreiber, S., DeFino, M., Kwan, S. C., Li, S., and Chavkin, C. (2007) Long-acting $\kappa$ opioid antagonists disrupt receptor signaling and produce noncompetitive effects by activating cJun N-terminal kinase. J. Biol. Chem. 282, 29803-29811.

(60) Potter, D. N., Damez-Werno, D., Carlezon, W. A., Cohen, B. M., and Chartoff, E. H. (2011) Repeated Exposure to the $\kappa$-Opioid Receptor Agonist Salvinorin A Modulates Extracellular SignalRegulated Kinase and Reward Sensitivity. Biol. Psychiatry 70, 744-753.

(61) Munro, T. A., Berry, L. M., Van't Veer, A., Béguin, C., Carroll, F., Zhao, Z., Carlezon, W. A., and Cohen, B. M. (2012) Long-acting ê opioid antagonists nor-BNI, GNTI and JDTic: pharmacokinetics in mice and lipophilicity. BMC Pharmacol. 12, 5.

(62) Owens, S. M., Pollard, G. T., Howard, J. L., Fennell, T. R., Snyder, R. W., and Carroll, F. I. (2016) Pharmacodynamic Relationships between Duration of Action of JDTic-like Kappa-Opioid Receptor Antagonists and Their Brain and Plasma Pharmacokinetics in Rats. ACS Chem. Neurosci. 7, 1737-1745.

(63) Placzek, M. S., Zhao, W., Wey, H. Y., Morin, T. M., and Hooker, J. M. (2016) PET Neurochemical Imaging Modes. Semin. Nucl. Med. 46, $20-27$.

(64) Guo, N., Guo, W., Kralikova, M., Jiang, M., Schieren, I., Narendran, R., Slifstein, M., Abi-Dargham, A., Laruelle, M., Javitch, J. A., and Rayport, S. (2010) Impact of D2 Receptor Internalization on Binding Affinity of Neuroimaging Radiotracers. Neuropsychopharmacology 35, 806-817.

(65) Neumeyer, J. L., Zhang, B., Zhang, T., Sromek, A. W., Knapp, B. I., Cohen, D. J., and Bidlack, J. M. (2012) Synthesis, binding affinity, and functional in vitro activity of 3-benzylaminomorphinan and 3benzylaminomorphine ligands at opioid receptors. J. Med. Chem. 55, 3878-3890.

(66) Rothman, R. B., France, C. P., Bykov, V., De Costa, B. R., Jacobson, A. E., Woods, J. H., and Rice, K. C. (1989) Pharmacological activities of optically pure enantiomers of the $\kappa$ opioid agonist, U50,488, and its cis diastereomer: evidence for three $\kappa$ receptor subtypes. Eur. J. Pharmacol. 167, 345-353.

(67) Leighton, G. E., Rodriguez, R. E., Hill, R. G., and Hughes, J. (1988) $\kappa$-Opioid agonists produce antinociception after i.v. and i.c.v. but not intrathecal administration in the rat. Br. J. Pharmacol. 93, 553560.

(68) Johnson, M. W., MacLean, K. A., Reissig, C. J., Prisinzano, T. E., and Griffiths, R. R. (2011) Human psychopharmacology and doseeffects of salvinorin A, a kappa opioid agonist hallucinogen present in the plant Salvia divinorum. Drug Alcohol Depend. 115, 150-155.

(69) Wang, Y., Chen, Y., Xu, W., Lee, D. Y., Ma, Z., Rawls, S. M., Cowan, A., and Liu-Chen, L. Y. (2008) 2-Methoxymethyl-salvinorin B is a potent kappa opioid receptor agonist with longer lasting action in vivo than salvinorin A. J. Pharmacol. Exp. Ther. 324, 1073-1083.

(70) van Giezen, J. J. J., Nilsson, L., Berntsson, P., Wissing, B. M., Giordanetto, F., Tomlinson, W., and Greasley, P. J. (2009) Ticagrelor binds to human P2Y12independently from ADP but antagonizes ADPinduced receptor signaling and platelet aggregation. J. Thromb. Haemostasis 7, 1556-1565.

(71) Porter, R. H. P., Jaeschke, G., Spooren, W., Ballard, T. M., Büttelmann, B., Kolczewski, S., Peters, J.-U., Prinssen, E., Wichmann, J., Vieira, E., Mühlemann, A., Gatti, S., Mutel, V., Malherbe, P., and Johnson, E. C. (2005) Fenobam: a clinically validated nonbenzodiazepine anxiolytic is a potent, selective, and noncompetitive mGlu5 receptor antagonist with inverse agonist activity. J. Pharmacol. Exp. Ther. 315, 711-721.

(72) Wu, H., Wacker, D., Mileni, M., Katritch, V., Han, G. W., Vardy, E., Liu, W., Thompson, A. A., Huang, X.-P., Carroll, F. I., Mascarella, S. W., Westkaemper, R. B., Mosier, P. D., Roth, B. L., Cherezov, V., and Stevens, R. C. (2012) Structure of the human $\kappa$-opioid receptor in complex with JDTic. Nature 485, 327-332.

(73) Vardy, E., Mosier, P. D., Frankowski, K. J., Wu, H., Katritch, V., Westkaemper, R. B., Aubé, J., Stevens, R. C., and Roth, B. L. (2013) Chemotype-selective modes of action of k-opioid receptor agonists. J. Biol. Chem. 288, 34470-34483.

(74) Tao Che, A., Majumdar, S., Zaidi, S. A., Katritch, V., Wacker, D., Roth, B. L., Che, T., Ondachi, P., McCorvy, J. D., Wang, S., Mosier, P. D., Uprety, R., Vardy, E., Krumm, B. E., Han, G. W., Lee, M.-Y., Huang, X.-P., Strachan, R. T., Tribo, A. R., Pasternak, G. W., Carroll, F. I., Stevens, R. C., Cherezov, V., and Roth, B. L. (2018) Structure of the Nanobody-Stabilized Active State of the Kappa Opioid Receptor In Brief Structure of the Nanobody-Stabilized Active State of the Kappa Opioid Receptor. Cell 172, 55-67.

(75) Vardy, E., Robinson, J. E., Li, C., Olsen, R. H. J., DiBerto, J. F., Giguere, P. M., Sassano, F. M., Huang, X.-P., Zhu, H., Urban, D. J., White, K. L., Rittiner, J. E., Crowley, N. A., Pleil, K. E., Mazzone, C. M., Mosier, P. D., Song, J., Kash, T. L., Malanga, C. J., Krashes, M. J., and Roth, B. L. (2015) A New DREADD Facilitates the Multiplexed Chemogenetic Interrogation of Behavior. Neuron 86, 936-946. 
(76) Lee, H. G., Milner, P. J., Placzek, M. S., Buchwald, S. L., and Hooker, J. M. (2015) Virtually Instantaneous, Room-Temperature [11C]-Cyanation Using Biaryl Phosphine $\mathrm{Pd}(0)$ Complexes. J. Am. Chem. Soc. 137, 648-651.

(77) Schiffer, W. K., Mirrione, M. M., Biegon, A., Alexoff, D. L., Patel, V., and Dewey, S. L. (2006) Serial microPET measures of the metabolic reaction to a microdialysis probe implant. J. Neurosci. Methods 155, $272-284$.

(78) Logan, J., Fowler, J. S., Volkow, N. D., Wang, G.-J., Ding, Y.-S., and Alexoff, D. L. (1996) Distribution Volume Ratios without Blood Sampling from Graphical Analysis of PET Data. J. Cereb. Blood Flow Metab. 16, 834-840.

(79) Innis, R. B., Cunningham, V. J., Delforge, J., Fujita, M., Gjedde, A., Gunn, R. N., Holden, J., Houle, S., Huang, S. C., Ichise, M., Iida, H., Ito, H., Kimura, Y., Koeppe, R. A., Knudsen, G. M., Knuuti, J., Lammertsma, A. A., Laruelle, M., Logan, J., Maguire, R. P., Mintun, M. A., Morris, E. D., Parsey, R., Price, J. C., Slifstein, M., Sossi, V., Suhara, T., Votaw, J. R., Wong, D. F., and Carson, R. E. (2007) Consensus nomenclature for in vivo imaging of reversibly binding radioligands. $J$. Cereb. Blood Flow Metab. 27, 1533-1539.

(80) Meng, F., Xie, G. X., Thompson, R. C., Mansour, A., Goldstein, A., Watson, S. J., and Akil, H. (1993) Cloning and pharmacological characterization of a rat kappa opioid receptor. Proc. Natl. Acad. Sci. U. S. A. $90,9954-8$. 